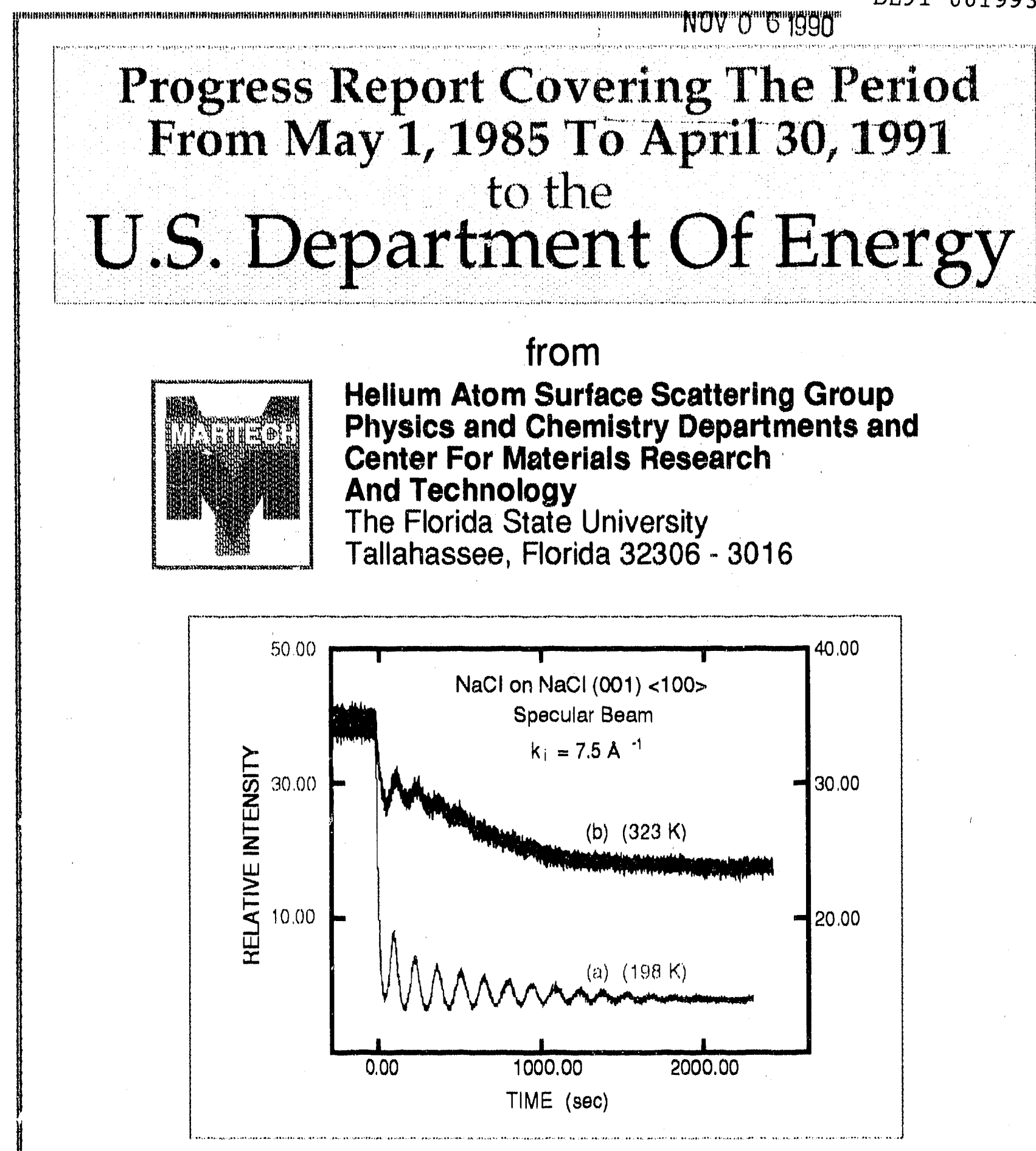

Project Title:

He Atom Surface Spectroscopy: Surface Lattice

Dynamics of Insulators, Metals and Metal Overlayers.

Experimental Scientists:

S.A. Safron, Associate Professor

J.G. Skofronick, Professor 
TABLE OF CONTENTS

Title page . . . . . . . . . . . . . . . . . . 1

Table of Contents . . . . . . . . . . . . . . . . 2

I. Project Abstract . . . . . . . . . . . . . . . . 3

II. High Resolution He Scattering Instrument . . . . . . . 5

III. Results . . . . . . . . . . . . . . . . . 6

IV. Facilitites and Personnel . . . . . . . . . . . 9

V. Collaboration . . . . . . . . . . . . . 10

VI. Activities of the Investigators . • • • . . . . . • . 11

VII. References . . . . . . . . . . . . . . . . . . . . 19

VIII. Figures . . . . . . . . . . . . . . . . 21

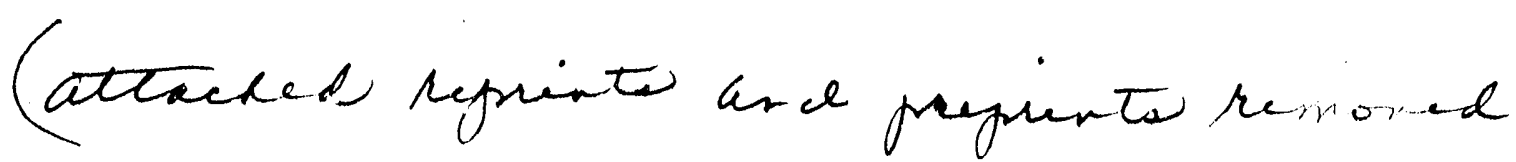
ard cyeled oegaratily) -

DISCLAIMER

This report was prepared as an accunt of work sponsored by an agency of the United States Government. Neither the United States Government nor any agency thereof, nor any of their employees, makes any warranty, express or implied, or assumes any legal liability or responsibility for the accuracy, completeness, or usefulnes: of any information, apparatus, product, or process disclosed, or represents that its use would not infringe privately owned rights. Reference herein (o) any specifis commercial product, process, or service by trade name, trademark, manufacturer, or otherwise does not necessarily constitute or imply its endorsement, recommendation, or favoring by the United States Government or any agency thereof. The views and opinions of authors expressed herein do not necessarily state or reflect those of the United States Government or any agency thereof. 


\section{PROJECT ABSTRACT}

During the first three years of this grant (1985-1988) the effort was devoted to the construction of a state-of-the-art He atom scattering (HAS) instrument which would be capable of determining the structure and dynamics of metallic, semiconductor or insulator crystal surfaces. The second three year grant period (1988-1991) has been dedicated to measurements. The construction of the instrument went better than proposed; it was within budget, finished in the proposed time and of better sensitivity and resolution than originally planned. The same success has been carried over to the measurement phase where the concentration has been on studies of insulator surfaces, as dirscussed below.

The experiments of the past three years have focussed primarily on the alkali halides with a more recent shift to metal oxide crystal surfaces. Both elastic anc inelastic scattering experiments were carried out on LiF, NaI, $\mathrm{NaCl}, \mathrm{RbCl}, \mathrm{KBr}, \mathrm{RbBr}$, $\mathrm{RbI}, \mathrm{CsF}, \mathrm{CsI}$ and with some preliminary work on $\mathrm{NiO}$ and MgO. The results can be summarized in the following: (1) The surface phonon dispersion relations for the alkali halide surfaces have been measured and compared with previous calculations. In general, the agreement is good for the Rayleigh wave, but there are important differences for higher-lying modes. (2) Many of these crystals seem to have crossing modes. That is, they have a mode which has non-zero frequency at the Brillouin zone center $\bar{\Gamma}$, crosses the acoustic band with negative group velocity and meets-up with the Rayleigh wave at $\overline{\mathrm{X}}$ and/or $\overline{\mathrm{M}}$. For $\mathrm{NaCl}$ this mode had been predicted, but not for $\mathrm{NaI}$ and $\mathrm{RbI}$. We have proposed an explanation for this apparentiy rather general behavior of the alkali halides (which likely carries over to other surface systems). (3) In $\mathrm{NaI}$ and in $\mathrm{NaCl}$ we observe some large peaks in the time-of-flight spectra which lie in the bulk bands. These apparently result from enhanced cross sections due to bound-state resonances. (4) The temperature dependence of the inelastic and elastic scattering intensities has been measured for $\mathrm{NaCl}$ and $\mathrm{NaI}$. Initially analyzed with a relatively simple model, these experiments then give the average number of phonons exchanged per He atom collision, as well as the Debye temperature for the surface. This work has now been extended to give infor ation on the form factor in the inelastic scattering expression, and thus can be used to extract He atom-surface potential information from the detailed multiphonon scattering investigations. (5) Evidence from experiments on the RbI crystal suggests, for the first time, that relaxation may indeed be responsible for new modes in the surface lattice dynamics of alkali halides and, therefore, probably in other ionic insulators as well. Our results in $\bar{\Gamma} \bar{M}$ of the surface Brillouin zone appear to comfirm a new high-lying optical mode, above the bulk bands, which was predicted in slab dynamics calculations which allowed for surface relaxation. In the $\bar{\Gamma} \bar{M}$ region we also find another optical mode which lies near the upper edge of the acoustic band that was not originally predicted by the theoretical model. (6) Homoepitaxial growth of $\mathrm{NaCl}$ vapor on a 
Nacl single crystal has been observed by monitoring the specular He beam signal as a function of coverage. The results indicate that the He specular intensity initially decreases by about $70 \%$ after which there is an oscillatory behavior indicating the layer-bylayer growth. The Bragg peaks behave similarly. (7) The use of a pulsed valve to replace the existing continuous source has been explored in some preliminary tests which indicate promise of improved velocity resolution. However, the tests indicate that further development is necessary.

The systems to be examined by high resolution He scattering in the near future are listed briefly below and explained in more detail in the separate three-year renewal proposal accompanying this progress report. (1) We plan further exploration of insulator materials. We now feel that the alkali halides have been rather thoroughly investigated, but that other non-alkali halide materials lack the necessary experimental data to allow further theoretical. treatment and model development. These materials include the metal oxides such as MgO and NiO (which we already have started), more molecular types of materials, starting with $\mathrm{KCN}$, and the perovskites such as $\mathrm{SrTiO}_{3}$. (2) our multiphonon studies on the alkali halides need to be extended to some additional metals and to semiconductors so that our theoretical model can be checked further. A: present we believe that the model allows us to find form factor (or He-surface potential) information which should prove useful for theorists working on the modeling of potentials. Further, knowing the form factor should allow us to find experimentally the surface phonon density of states, a long sought goal of many of us. (3) We are planning to begin an investigation of the self-assembling alkyl thiol monolayers on $\mathrm{Au}$ (111) and Ag (111). He atom diffraction experiments at low temperatures have shown that these materials form ordered domains. However, the inelastic studies we propose will explore the forces responsible for the ordering and the mobility of the head groups. (4) We have initiated studies of epitaxial growth, starting with homo- and heteroepitaxial growth on the alkali halides. A literature search indicates that no information on epitaxial growth is available by HAS for the alkali halides even though there are suggestions that these crystals might be unique for such studies. Our preliminary work indicates that we have opened up a rather substantial new area of research. HAS scattering may be the only probe that can easily study the growth of insulators. Our intent is to characterize the growth of the alkali halides and then move to oxides, probably starting with epitaxial growth on Nio. Some of the more complex materials for the epitaxial growth studies could be made in an existing molecular beam epitaxy (MBE) instrument and transferred under vacuum to the HAS apparatus. Further work might also employ the new Chemistry Department MOCVD facility. (5) We are planning a series of studies on the surface properties of magnetic materials. In this regard we are influenced by two circumstances. The first is that we have available an MBE facility which our colleagues are using to produce magnetic superlattices such as 
$\mathrm{NiO} / \mathrm{Fe}_{3} \mathrm{O}_{4}$ combinations. We believe our HAS capabilities would substantially further the understanding of the substrates used, of the growth properties, and of the interface characterization. At the present time the characterization is at best qualitative and often simply lacking. The second circumstance involves the recent funding by the NSF of a National High Magnetic Field Laboratory here at FSU. We believe that this provides us with a unique opportunity for investigating magnetic effects on surfaces. In particular, we would search for spin waves coupled to phonon modes which would give us a good handle on surface magnetization. Bulk studies of this nature have been done and the surface manifestation of spin waves coupled to surface phonons cught to exist also.

\section{HIGH RESOLUTION He BCATTERING INSTRUMENT}

The details of the scattering instrument have been published and are shown schematically in Figures 1 and 2. [1] Briefly, the He beam is produced as a nozzle jet in the source chamber with a velocity spread $\Delta \mathrm{v} / \mathrm{v} \approx 1 \%$. The beam passes through the skimmer into the chopper chamber. For the inelastic scattering experiments the beam is chopped into pulses which are employed in a time-of-flight (TOF) technique for determining the energy transferred; for the angular distribution experiments the chopper is displaced out of the beam path. In both cases the atoms then pass through two stages of differential pumping to the target chamber where they collide with the crystal. At the present time the angle between the incoming beam and the detector axis is fixed at $90^{\circ}$. The scattered He atoms then pass through four stages of differential pumping to the detector chamber where their flux is measured by a quadrupole mass spectrometer operated in a pulse-counting mode.

currently, the He wave vector (energy) can be varied from about $6.2-12 \AA^{\prime-1}(20-75 \mathrm{meV})$ by changing the temperature of the nozzle. The crystal temperature can be varied from about $120 \mathrm{~K}$ to over $1000 \mathrm{~K}$. The chopper is normally operated at a frequency of $320 \mathrm{~Hz}$ to give pulses with a FWHM o: $7 \mu \mathrm{s}$. In a TOF experiment the operating pressures in the target and detector chambers are about $5 \times 10^{-10}$ torr and $5 \times 10^{-11}$ torr, respectively, and in the beam path between the crystal and the detector about $2 \times 10^{-9}$ torr.

The crystal is mounted onto a manipulator which allows it to be aligned in the proper orientation (at the intersection of the beam and detector axes) by permitting translation in the $x, y$ and $z$ directions, azimuthal rotation and several degrees of tilting. The manipulator itself is mounted on a differentially pumped rotatable platform so that the incident angle of the He beam onto the crystal, $\theta_{i}$ (measured normal to the crystal surface), may be changed without disturbing the alignment controls. A stepper motor under crnputer control is used to drive the platform. The He beam strikes a target area of roughly $5 \mathrm{~mm}^{2}$ at the crystal. The area is controlled by a movable aperture and can be reduced to approximately $1 \mathrm{~mm}^{2}$. The calculated angular resolution (FWHM) of the 
detector is approximately $0.15^{\circ}$ in agreement with the experimental value.

The data acquisition system consists of a computer-controlled CAMAC interface which interacies directly with the instrument. The heart of this system is a custom-made multichannel scalar (Lawrence Livermore Laboratory) which is used for the time-of-flight measurements.[2] A security system protects the instrument from damage due to power, water or vacuum failure.

The more recent construction efforts have been directed toward (1) the completion of a separate test chamber which is used to characterize samples before insertion into the scattering chamber (now finished) and (2) toward improving the capabilities of the HAS instrument. The latter includes an evaporator arrangement for epitaxial growth studies on alkali halide crystals (finished and currently being used), a conversion from cooling the crystal by liquid nitrogen to a mechanical refrigerator (underway), the construction of a movable cart for transfering under vacuum samples prepared in our MBE machine to the HAS instrument (finished, but not tested), a crystal cleaving device for in situ cleaving of crystals (tested in air, but not in vacuum) and some further studies on pulsed valves for use as the beam source (results being analyzed).

\section{RESULTS}

Summaries of the principal results of the experimental efforts for the last three years are given here. The details may be found in the preprints and reprint appended to this report.

1. Surface Phonon Dispersion Curves. The surface phonon dispersion curves of $\mathrm{NaI}[3], \mathrm{NaCl}[4,5], \operatorname{RbCl}[6], \operatorname{KBr}[1], \operatorname{RbBr}[7]$, $\mathrm{RbI}[8], \mathrm{CsF}[9], \mathrm{NiO}[10]$ and $\mathrm{MgO}[10]$ have been measured by this group during this period. A limited summary of these results is shown in Figures $3-5$ for $\mathrm{KBr}, \mathrm{NaCl}$ and $\mathrm{RbI}$, respectively. Where appropriate, they are plotted on top of calculations by Benedek and Miglio[11,12] who employ a Green's function technique and/or by de Wette and co-workers $[13,14]$ who use a slab dynamics approach. In general, the agreement is good for the Rayleigh wave (the slab dynamics calculation is a little high for NaCl), but there are clearly other experimental details which do not seem to match. In all three, but most clearly in $\mathrm{KBr}$, there is evidence for crossing modes: modes which appear as optical modes in that they have nonzero frequency at the Brillouin zone center $\bar{\Gamma}$ and cross the acoustic bands with negative group velocity, meeting the Rayleigh wave at the zone boundaries $(\bar{X}$ and $\bar{M})$. One should perhaps note that because of the large masses of the ions in RbI, its Rayleigh wave represents the lowest energy dispersion which has been obtained in surface studies.

2. Crossing Modes due to structure-Induced Resonances. In all the alkali halides which have been studied by high resolution He atom scattering, except for LiF[15], RbCl, and CsF, crossing modes have been observed. The best examples of these are probably 
in $\mathrm{NaF}[16], \mathrm{KBr}$ (Figure 3), $\mathrm{RbBr}$ and $\mathrm{RbI}$ (Figure 5). Two explanations had been offered. Benedek and co-workers [16] extended the argument of Foldy and co-workers[17] for the bulk dispersion curves to the iwo-dimensional case. Namely, in nearly isobaric crystals (nearly identical cation and anion masses) the vibrational pattern should resemble that of the monatomic crystal with half the lattice spacing and twice the Brillouin zone. Thus, the acoustic mode extending over the entire monatomic Brillouin zone should fold back into the smaller true zone; the second half of this curve would then appear in the true zone as the crossing mode. That is, Benedek et al. proposed that a crossing mode should exist for the nearly isobaric crystals. On the other hand, de wette and coworkers[18] suggested that a crossing mode or sagittal resonance occured whenever there is a hybridization (or polarization exchange) between the $\mathrm{TA}_{1}$ and $\mathrm{TO}_{1}$ bulk modes in the $\langle 110\rangle$ direction. However, we noticed[19] that the dispersion of the crossing modes in our measurements, as well as in previous measurements, in $\bar{\Gamma} \overline{\mathrm{X}}$ seemed to follow that of part of the bulk $\mathrm{TA}_{2}$ mode in the <110> direction and that in $\vec{\Gamma} \dot{M}$ seemed to be very similar to the transverse acoustic modes from $x$ to $w$ to $x$ along the boundaries of the three-dimensional Brillouin zone. Further, we found that a crossing mode existed even when the conditions suggested by both groups above were not followed, as in $\mathrm{NaI}, \mathrm{KBr}$ and $\mathrm{RbI}$. In fact, the condition for a crossing mode seems to be analogous to that suggested for a structure-induced resonance in metals by stroscio et al.[20]. For these compounds this is an avoided crossing between the bulk LA and Lo curves in the <100> direction.

3. Bound-state Resonances in the Inelastic scattering. Celli and co-workers[21] have shown that bound states in the He-crystal surface potential can result in enhanced inelastic scattering events if certain resonant conditions are met. We seem to have found further evidence for this effect in both $\mathrm{NaI}$ and $\mathrm{NaCl}$. [5] In Figure $4 \mathrm{a}$ is shown a dispersion curve for $\mathrm{NaCl}$ with points in the bulk bands not associated with any surface modes, while Figure $4 \mathrm{~b}$ has been modified to remove the bulk phonon resonances associated with the known bound states.

4. Multiphonon scattering of He from surfaces. Our group has collaborated with Professor Manson of Clemson University and developed a model for the scattering of He from surfaces where multiphonon interactions take place as the target temperature is raised. originally $[4,22]$ the model was developed as a limiting case, but our most recent approach [23] gives an explanation of the multiphonon inelastic scattering process with good quantitative agreement with experimental data. Some results for $\mathrm{NaCl}(001)$ and Al(111) are shown in Figures 6 and 7 which have both the experimental results and the theoretical fit. What we find surprising in the comparison is that tre shape of the multiphonon background strongly depends on the interaction potential and much less so on the details of the phonon spectrum. What has become evident from this study is that the inelastic multiphonon scattering can be used to obtain important information on the He- 
surface potential and consequently on the form factor in the scattering process. This is important for single phonon scattering studies because the one-phonon inelastic expression has both the form factor and the phonon density of states in it. Up to now we have relied mainly on models for both of these. In the future, we expect that knowing the form factor will allow us to find the phonon density of states completely from experiment. This determination would greatly aid in the theoretical development.

5. Relaxation of the Alkali Halide (001) surfaces. De Wette and co-workers[14] have extended the shell model treatment of the lattice dynamics of alkali halides to allow for surface relaxation. Their predictions are that the relaxation effects are small except for some of the heavier alkali halides sush as $R b B r$ and $R b I$. In our previous work on $\mathrm{KBr}$ and, particularly, on $\mathrm{RbBr}$ the results seemed to imply that the relaxation was negligible. Most importantly in this regard, we failed to observe the $\mathrm{S}_{2}$ mode which was predicted to shift above the optical band in $\mathrm{RbBr}$ because of the relaxation. Now, in $\mathrm{RbI}$ we appear to have found the high-lying $\mathrm{S}_{2}$ mode, at least in $\bar{\Gamma} \overline{\mathrm{M}}$ of the surface Brillouin zone, and it lies not very far from the predicted frequencies, as can be seen in Figure 5. In the $\bar{\Gamma} \bar{X}$ region we also find good agreement with another sagittal plane optical mode that is modified by relaxation. (Compare the upper and lower panels in Figure 5.) This mode has been shifted dornward in energy and its character has been changed in the relaxed case to motion of predominantly I rather than of $\mathrm{Rb}^{+}$. Of great interest is another mode that is seen beginning near $\bar{M}$ with $\omega \sim 1.2 \times 10^{13} \mathrm{rad} / \mathrm{s}$ and continuing with downward slope to about a third of the way towards the zone center. This mode is not predicted by theory and it is speculated that it arises from a large second layer vibration of the $\mathrm{Rb}^{+}$. These results indicate that (1) the HAS experiments can map both low energy as well as high energy surface modes, (2) the shell model provides good agreement with the experimental results, (3) yet there are new modes which were not predicted and (4) surface relaxation seems to be confirmed by the observation of the high-lying $s_{2}$ mode.

6. Epitaxial Growth of Nacl on Nacl. We have initiated a research effort in epitaxial growth with insulating surfaces and include resilts here for the homoepitaxial growth of $\mathrm{NaCl}$ on $\mathrm{NaCl}$, our first effort which is currently underway. Figure 8 shows a curve of the specular He signal as a function of coverage for two different substrate temperatures where the intensity oscillations for the layer-by-layer growth are clearly seen. Our motivation for starting with the alkali halides is that we are very familiar with these materials and that some growth and characterization studies on these systems using RHEED as a monitor for the growth has been done[24]. That work indicated that the alkali halides grow under different conditions than those for metals and semiconductors because of their ionic bonding. Thus, studies of the alkali halides could lead us to a better understanding of epitaxial growth for ionic systems, and perhaps, for system in general. As an example of the power of HAS in surface studies, in Figure 9 the 
upper and lower panels show diffraction patterns obtained at the top and at the bottom, respectively, of the first oscillation in Figure $8 \mathrm{with} T \approx 198 \mathrm{~K}$. It shows that the surface is ordered in both coverages with the same lattice spacing, but with different corrugations. More experiments need to be carried out in order to interpret the process of the growth of this crystal. Obviously, studies of the homo- and heteroepitaxy of the alkali halides, with different substrate temperatures, different growth rates and probe energies need to be done, and most importantly, the time-of-flight capabilities of HAS have to be used to energy-analyze the scattered signal. For RHEED, this is a difficult experiment to carry out and interpret. We can do this quite readily as the results in items (1) - (5) above demonstrate.

7. Studies on a pulsed valve source. We have had a long standing interest in exchanging our current continuous source with a pulsed beam source which should give us more intensity and a more monochromatic velocity distribution. There are a number of commercially available sources around, but only one seems to have the capability of operating much below room temperature. our preliminary work was done on this valve which could be operated at $-100^{\circ} \mathrm{C}$. We found that indeed, this pulsed source gave a better signal-to-noise and a more monochromatic beam than the continuous source, as is shown in Figure 10. However, there are problems in that the repetition rate was about a factor of four less than the chopped continuous beam, thus offsetting the net signal gain. We have concluded that the pulse rate needs to be improved and, further, the modifications which allow it to be able to operate at even lower temperatures need to be examined. We are currently exploring these features with the manufacturer.

\section{FACILITIES AND PERSONNEL}

The support facilities for this project include the Machine and Electronic shops of both the Physics and Chemistry Departments. The employees of these shops are paid by the state of Florida and are normally available on a first-come-first-serve basis. In addition, the MTRTECH program which the state has set-up and funded at FSU, has personnel experienced in growing and handing crystals and thin films, and in operating an ESCA surface analysis station. More recently, a program of Molecular Beam Epitaxy has been developed here that is being used to study magnetic superlattices. In addition, there are new facilities for $x$-ray, scanning electron microscope, ellipsometric and i.r. examination of crystal samples which are readily available on a limited basis to us and a facil : for MOCVD which is currently being installed. With the location ol: the new National High Field Magnetic Lab to be at FSU, we expect in the future to use HAs in problems of concern to the understanding of magnetic phenomena.

The Florida State University also has established the DOE-FSU sponsored Supercomputer Computations Research Institute (SCRI) which has a Cray $\mathrm{Y}-\mathrm{MP}$ and a massively parallel Connection Machine. 
This facility is very well suited for collaborative ventures between our group and visiting theorists. We have already used it thusly and plan to continue (as explained in the next section).

The current scientific personnel consist of the principal and senior investigators, JGS and SAS, and four dedicated graduate students, G. G. Bishop, E. S. Gillman and J. Duan (Physics) and W. P. Brug (Chemistry). Our first student G. Chern has completed his doctoral dissertation and has worked part-time with us as a postdoctoral associate. Brug, a fifth year graduate student in Analytical Chemistry currently writing his dissertation, has been doing most of the software development for the lata acquisition system; he has completed the RbI studies and has carried out very preliminary experiments on $\mathrm{NiO}$ and $\mathrm{KCH}$. Duan is a fourth year student who has worked on the $\mathrm{NaI}$ and $\mathrm{NaCl}$ experiments and is now involved with the epitaxial growth experiments. Bishop is a third year student and has helped with the experiments and the data analysis, particularly with the temperature-dependent, multiphonon experiments. Gillman is a second year student and has been working on the pulsed He valve. Professor Betty Derrick of Valdosta state College, Georgia, spent a summer (1987) with us under a grant to the chemistry Department and continues this effort when her teaching schedule permits. We have had several undergraduate students, both male and female, spend summers with us. These students were supported uy a NSF grant to the FSU Physics Department for Undergraduate Research Participation. Finally, we have also had a couple of students in the University Honors Program spend a semester in our laboratory.

\section{v. COLLABORATION}

We have had a long-standing collaboration with the surface scattering group of the Max Planck Institut für strömungs-forschung (MPI) in Göttingen, directed by Frofessor J. Peter Toennies. One of us (JGS) has had a NATO grant to carry out experiments at the MPI, which has resulted in about a dozen published papers. More recently, we have been awarded another NATO grant for further cooperative efforts between our group and the experimental group in Göttingen as well as the theory group of Benedek and Miglio in Milan, Italy. During this year (December) we will have one of the German post-doctoral students spend three to four weeks here to help us learn about some of the computer codes which have been developed there for lattice dynamics calculations and for simulations of experimental results.

As mention earliex, we have also collaborated at FSU with two Italian theorists, Professor Leo Miglio of the University of Milan and his former student Luciano Colombo who has just started a faculty position in Milan. Thanks to time on the SCRI computers provided by the waterial Science Division of DOE, and financial assistance provided by the supercomputer computations Research Institute (SCRI) and MARTECH at FSU, they were able to spend two montrs (1988) here to calculate the lattice dynamics of some metal and semiconductor superlattice materials. Last summer (1ฐ89) Dr. 
Colombo was able to return to FSU for three weeks to carry out additional calculations. We expect to have another advanced student from that group again this year in association with the NATO grant and also partially supported in-house. This work and its future extensions will be of great value to us in our experiments with epitaxial growth.

To interpret and understand the results of our experiments requires continuing close collaborations with theorists. As examples of this, we point to the collaborations in the interpretation and understanding of the crossing modes in the alkali halides with Professor Giorgio Benedek of the University of Milan and in the development of the temperature-dependent, multiphonon scattering model with Professor J. R. Manson of Clemson University, noted earlier. We intend to remain associated, in addition, with the theoretical students of the MPI and with Professor celli at the University of Virginia, a pioneer in surface-scattering theory. Further, Professor F. W. de Wette from the University of Texas-Austin, a pioneering surface lattice theorist and a strong proponent of surface studies on the alkali halides and other insulators, is very much interested in helping us interpret our new results on RbI. Professors schroeder from the University of Regensburg and Kress from the MPI for Festkörperforschung in stuttgart, Germany, are interested in the lattice dynamics of the molecular crystals and perovskites.

\section{ACTIVITIES OF THE INVESTIGATORS}

The principal effort for both of us has been to build the HAS instrument and then to develop the techniques of He atom scattering as a probe of the dynamical behavior of surfaces, primarily through the investigations on the alkali halides and other insulating surfaces. The construction of the instrument is complete and we are very pleased with the results so far.

In addition, both of ' $\lambda$ s have been active in the international surface science community during this period. A list of the activities is given below along with a list of the papers published. These include the collaborative work of one of us (JGS) with the MPI and Milan group and some reactive scattering studies by the other (SAS).

A. Papers submitted during the Period May 1, 1985 to April $30,1991$.

1. Surface Optical phonons in NaF (001) $\langle 100\rangle$ by Inelastic He Atoms Scattering. G. Benedek, G. Brusdeylins, L. Miglio, R. Rechsteiner, J. G. Skofronick and J. P. Toennies. Phys. Rev. Letters 54, $446(1985)$.

2. Characterization of a Piezoelectric Pulsed Nozzle Beam, P. Andresen, M. Faubel, D. Haeusler, G. Kraft, H. W. Luelf, and J. G. Skofronick, Rev. Sci. Instrum. 562038 (1985). 
3. Sequential Impulse Model for Chemical Reactions: A Comparison of Reactive Scattering Contour Diagrams for

Limiting Cases, S. A. Safron, J. Phys. Chem. 89, 5713-5719 (1985).

4. Sequential Impulse Model for Knockout Reactions: A Comparison with Crossed Beam Scattering Experiments", S. A. Safron, J. Phys. Chem. ㅇ, 5719-5722 (1985).

5. Localized Surface Optical Modes in a Layered crystal Gase (001), G. Brusdeylins, R. Rechsteiner, J. G. Skofronick, J. P. Toennies, G. Benedek and L. Miglio, Phys. Rev.B34, 902 $(1986)$.

6. Temperature Dependent Surface Structure and Dynamics of $2 \mathrm{H}-\mathrm{TaSe}_{2}$ (0001) studied by He-Atom Diffraction, G. Brusdeylins, C. Heimlich, J. G. Skofronick, J. P. Toennies, R. Volimer, G. Benedek and L. Miglio, Vuoto XVI, 202 (1986).

7. New Evidence for the Folding of Surface Phonon Modes in Quasimonatomic Crystals from He Time-of-Flight Measurements in NaF, G. Benedek, L. Miglio, G. Brusdeylins, J. G. Skofronick and J.P. Toennies, Phys. Rev. B35, 6593 (1987).

8. Determination of the Potential for simultaneous Rotational Excitation and Diffraction in Scattering of $D_{2}$ from LiF, $G$. Brusdeylins, G. Drolshagen, A. Kaufhold, J. G. Skofronick and J. P. Toennies, Surf. Sci. 189/190, 972 (1987).

9. Surface Phonon Dynamics in $2 \mathrm{H}-\mathrm{TaSe}_{2}(001), \mathrm{G}$. Benedek, L. Miglio, J. G. Skofronick, G. Brusdeylins, C. Heimlich and J. P. Toennies, J. Vac. Sci. Technol. A5, 1093 (1987).

10. Surface Phonon Dynamics in $2 \mathrm{H}-\mathrm{TaSe}_{2}(001), \mathrm{G}$. Benedek, L. Miglio, G. Brusdeylins, C. Heimlich, J. G. Skofronick and J. P. Toennies, Europhys. Lett. 5,253 (1988).

11. Shifted Surface Phonon Anomaly on $2 \mathrm{H}-\mathrm{TaSe}_{2}, \mathrm{G}$. Benedek, G. Brusdeylins, C. Heimlich, L. Miglio, J. G. Skofronick, J. P. Toennies and R. Vollmer, Phys. Rev. Lett. 60, 1037 (1988).

12. Surface Phonon Dispersion Curves via Thermal Energy Atom Scattering (TEAS): He Atoms on RbCl (001) Surface, G. Chern, W. P. Brug, S. A. Safron and J. G. Skofronick, J. Vac. Sci. Technol. A7, 2094 (1989).

13. Surface Phonon Dispersion Curves of $\mathrm{KBr}$ (001) via Thermal Energy Atom Scattering (TEAS): A Comparison with Calculations, G. Chern, J. G. Skofronick, W. P. Brug and S. A. Safron, Phys. Rev. B39, 12828 (1989). 
14. Surface Phonon Modes of the RbBr(001) Crystal Surface by Inelastic He Atom Scattering, G. Chern, J, G. Skofronick, W. P. Brug and S. A. Safron, Phys. Rev. B39, 12838 (1989).

15. Determination of the Critical Exponent for a Charge Density Wave Transition in $2 \mathrm{H}-\mathrm{TaSe}_{2}$ by Helium Atom Scattering, $\mathrm{G}$. Brusdeylins, C. Heimlich, J. G. Skofronick, J. P. Toennies, R. Volimer and G. Benedek, Europhys. Lett. 9,563 (1989).

16. NaI Surface Phonon Modes by Inelastic He Atom Scattering, J. G. Skofronick, w. P. Brug, G. Chern, J. Duan, S. A. Safron and G. Benedek, J. Vac. Sci. Technol. A8, 2632 (1990).

17. Surface Dynamics of $\mathrm{NaCl}$ (001) by Inelastic He Atom Scattering, S. A. Safron, W. P. Brug, G. Chern, J. Duan, J.G. Sknfronick and J. R. Manson, J. Vac. Sci. Technol. A8, $2627(1990)$.

18. He-Atom Scattering Study of the Temp rrature-Dependent Charge-Density-Wave Surface structure and Lattice Dynamics of $2 \mathrm{H}-\mathrm{TaSe}_{2}(001), \mathrm{G}$. Brusdeylins, C. Heimlich, J. G. Skofronick, J. P. Toennies, R. Vollmer, G. Benedek and L. Miglio. Phys, Rev. B41, 5707 (1990).

19. A Search for Cold Fusion using X-ray Detection, M. R. Deakin, J. D. Fox, K. W. Kemper, E. G. Myers, W. N. Shelton and J. G. Skofronick, Phys. Rev. C40, R1851 (1989).

20. Interpretation of Features in the Surface-Phonon Dispersion Curves of $\mathrm{KBr}(001)$ and $\mathrm{RbBr}(001)$, S. A. Safron, G. Chern, W. P. Brug, J. G. Skofronick and G. Benedek, Phys. Rev. B 4 1, 10146 (1990).

21. Temperature Dependence of He Atom Scattering from $\mathrm{NaCl}(001)$, J. G. Skofronick, G. G. Bishop, W. P. Brug, G. Chern, J. Duan, S. A. Safron and J. R. Manson, (Accepted by Superlattices and Microscructures, June, 1990).

22. Surface Lattice Dynamias of the RbI(001) Crystal surface via Inelastic He Atom Scattering, S. A. Safron, W. P. Brug, G. G. Bishop, J. Duan, G. Chern, and J. G. Skofronick, (Accepted by J. Elect. Spectios. Related Phenom., Sept., 1990).

23. Surface and Bulk Phonon-assisted Resonances with Surface Bound states in the Inelastic scattering of He Atoms on NaCl (001), S. A. Safron, W. P. Brug, G. G. Bishop, G. Chern, M. E. Derrick, J. Duan, M. E. Deweese and J. G. Skofronick, (Accepted by J. Vac. Sci. Technol., 1990). 
24. Surface Properties of CsF by He Atom Scattering, J. G. Skofronick, J. Duan, G. Chern, W. P. Brug, G. G. Bishop and S. A. Safron, (Submitted to Surface Science)

\section{B. Papers and posters Presented at conferences During the Period May 1, 1985 to April 30, 1991 .}

1. Characteristics of a Piezoelectric Pulsed Nozzle Beam, J.G. Skofronick, P. Andresen, M. Faubel, D. Haeusler, G. Kraft, and H.W. Luelf, Int. Symp. on Molecular Beams, Ed. by F. M. Devienne, I-Ll, Cannes, France, June, 1985.

2. Surface Acoustic and Optical Phonon Dispersion Relations for GaSe, J. G. Skofronick, G. Brusdeylins, J. P. Toennies, G. Benedek and L. Miglio, Bull. An. Phys. Soc. 31, j08 $(1986)$.

3. Elastische und Inelastische Heliumstreuung an den Schicht-Einkristallen $1 \mathrm{~T}-\mathrm{TaS}_{2}$ und $2 \mathrm{H}-\mathrm{TaSe}_{2}$ (Charge-Density-Waves), G. Brusdeylins, C. Heimlich, J. P. Toennies and J.G. Skofronick, DPG - Fruejahrstagung Freudenstadt, FRG 7-11, April (1986).

4. Hard Sphere Sequential Impact Model for Endo- and Exoergic Reactions, S. A. Safron and G. W. Coppenger, Southeastern Theoretical Chemists Association, Florida State University, May, 1986.

5. Folding of Surface Phonon Dispersion Curves in Nearly Isobaric Alkali Halide Crystals, J. G. Skofronick, G. Benedek, L. Miglio, G. Brusdeylins, and J.P. Toennies, at the Workshop on Interactions of Molecular Beams and Surfaces held in The Netherlands, Sept. 22-25, 1986.

6. Helium Diffracton studies of Charge-Density Wave Reconstruction in Tantalum disulfide $\left(1 \mathrm{~T}-\mathrm{TaS}_{2}\right), \mathrm{G}$. Benedek, G. Brusdeylins, C. Heimlich, J. G. Skofronick and J. P. Toennies, at the Workshop on Interactions of Molecular Beams and Surfaces held in the Netherlands, Sept. 22-25, 1986.

7. Temperature Dependent Surface structure and Dynamics of $2 \mathrm{H}-\mathrm{TaSe}_{2}(0001)$ studied by He-Atom Scattering, G. Benedek, G. Brusdeylins, C. Heimlich, J. G. Skofronick and J. P. Toennies, at the Workshop on Interactions of Molecular Beams and Surfaces held in The Netherlands, Sept. 22-25, 1986.

8. Surface Phonon Dynamics of 2H-TaSe, $(001), \mathrm{G}$. Benedek, L. Miglio, J. G. Skofronick, G. Brusdeylins, C. Heimlich, and J P. Toennies. At the $33 \mathrm{rd}$ National Symposium, American Vacuum Society, oct. 27-31, 1986, Baltimore, Maryland. 
9. Temperature Dependent Elastic and Inelastic He-Atom Studies of the $2 \mathrm{H}-\mathrm{TaSe}_{2}(0001)$ Surface, G. Brusdeylins, C. Heimlich, J. G. Skofronick, J. P. Toennies and R. Vollmer, 4 th Workshop on Surface Phonors, Schloss Ringberg, June (1987).

10. Charge-Density-Wave Reconstruction in Tantalum Disulfide (IT-TaS $)$ Probed with a High Resolution Helium Nozzle Beam, G. Brusdeylins, C. Heimlich, J. G. Skofronick and J. P. Toennies, XI Intern. Symp. On Molecular Beams, Univ of Edinburgh, July (1987).

11. Elastic and Inelastic He-Atom scattering studies of the 2H-TaSe 2 (0001) Surface, G. Brusdeylins, C. Heimlich, J. G. Skofronick, J. P. Toennies, R. Vollmer, G. Benedek and L. Miglio, 5th Int. Conf. Vibrations at Surfaces, Grainau-Eibsee, FRG Sept. (1987).

12. Surface Dynamics of $\mathrm{RbCl}$ and LiF by Inelastic He Atom Scattering, S. A. Safron, G. Chern, W. P. Brug and J. G. Skofronick, Southeastern Theoretical Chemists Association, Emory University, Atlanta, May, 1.988.

13. A study of the Charge Density Wave Transition in $2 \mathrm{H}-\mathrm{TaSe}_{2}$ by He Atom Scattering, G. Benedek, G. Brusdeylins, C. Heimlich, J. G. Skofronick, and J. P. Toennies, 6th Interactions of Molecular Beams and Surfaces, Sept. 12-16, Aussois, France (1988).

14. Surface Phonon Dispersion Curves via He Atom-Surface Spectroscopy (HASS): RbCl(001) and RbBr(001), G. Chern, W. P. Brug, S. A. Safron and J. G. Skofronick, 6th Interaction of Molecular Beam: and Surfaces, Sept. 12-16, Aussois, France (1988).

15. Surface Phonon Dispersion Curves of $\mathrm{RbCl}$ by Inelastic He Atom Scattering, S. A. Safron, G. Chern, W. P. Brug and J. G. Skofronick, American Vacuum Society, annual symposium, Atlanta, October, 1988.

16. Surface Phonon Modes of the RbBr (001) Crystal Surface by Inelastic He Atom Scattering, J. G. Skofronick, G. Chern, W. P. Brug and S. A. Safron, Bull. Am. Phys. Soc. 34, 724 (1989).

17. Surface Phorion Dispersion Curves of $\mathrm{KBr}$ (001) via Thermal Energy Atom Scattering (TEAS): A Comparison with Calculations, G. Chern, J. G. skofronick, W. P. Brug and S. A. Safron, Bull. Am. Phys. Soc. 34, 724 (1989).

18. Surface Dynamics of NaCl (001) by Inelastic He Atom Scattering, S. A. Safron, W. P. Brug, G. Chern, J. Duan, J. 
G. Skofronick and J. R. Manson, Dynamics of Gas-Surface Interactions Gordon Research Conference, New Hampshire, August, 1989.

19. Surface Dynamics of NaCi (001) by Inelastic He Atom Scattering, S. A. Safron, W. P. Brug, G. Chern, J. Euan, J. G. Skofronick and J. R. Manson, American Vacuurn Society, annual symposium, Boston, October, 1989.

20. Temperature Dependence of He atom Scattering from NaCl, J.G. Skofronick, G. Bishop, W. P. Brug, G. Chern, J. Duar, S. A. Safron and J. R. Manson, International Workshop on Surface Dynamics, Nov 10-11, Univ of Texas, Austin, TX (1989).

21. Helium Atom Scattering from $1 \mathrm{~T}-\mathrm{TaS}_{2}$ (001) Single crystal Surfaces, G. Brusdeyiins, F. Hofmann, J. P. Toennies, R. Vollmer, G. Benedek, P. Ruggerone and J. G. Skofronick, PHONONS 89 , Ed. by S. Hunklinger, W. Ludwig and G. Weiss, World Scientific, Singapore, 892 (1990).

22. Interpretation of Features in the (001) Surface Vibrational Modes of $\mathrm{KBr}$ and $\mathrm{RbBr}, \mathrm{S}$. A. Safron, G. Chern, W. P. Brug, J. G. Skofronick and G. Benedek, PHONONS 89, Ed. by S. Hunklinger, W. Ludwig and G. Weiss, World Scientific, Singapore, 949 (1990).

23. Elastic and Inelastic He Atom Scattering on $\mathrm{NaI}(001)\langle 110\rangle$, J.G. Skofronick, G. Chern, W. P. Brug, S. A. Safron and J. R. Manson, PHONONS 89 , Ed. by S. Hunklinger, W. Ludwig and G. Weiss, World Sciєitific, Singapore, 889 (1990).

24. Temperature Dependence of the Elastic and Inelastic Scattering of Helium from the NaCl (001) surface, G. G. Bishop, J. Duan, P. W. Brug, J. G. Skofronick, S. A. Safron and J. R. Manson, 19th Annual. Symp. on Applied Vacuum Sci. and Technol., Feb. 5-7, Clearwater Beach, FL (1990).

25. Surface Phonon Dispersion Curves of the R.bI (001) Surface by Inelastic He Atom Scattering, S. A. Safron, G. Chern, W. P. Brug, J. Duan, and J. G. Skofronick, American Physical Society, national meeting, Anaheim, March, 1990.

26. The Determination of RbI (001) Lattice Dynamics via High Resolution He Atom Scattering, W. P. Brug, S. A. Safron, G. G. Bishop, J. Duan, G. Chern and J. G. Skofronick, American Chemical Society, Florida Section meeting, Jacksonville, May, 1990.

27. Studies of Several Alkali Halide Crystal Surfaces by Inelastic Helium Atom Scartering, J. G. Skofronick, S. A. Safron, G. Chern, W. P. Brug, J. Duan and C. G. Bishop, 
Fifth Workshop on Surface Phonons; Schloss Ringberg, w. Germany, June 24-28, 1990.

28. Surface Lattice Dynamics of the RbI (001) Crystal Surface via Inelastic He Atom Scattering, S. A. Safron, W. P. Brug, G. G. Bishop, J. Duan, G. Chern and J. G. Skofronick, Vibrations at Surfaces VI, Shelter Island, New York, September, 1990.

29. Surface Phonon Dispersion Curves in Alkali Halides: Similarities and Differences, S. A. Safron, W. P. Brug, G. Chern, J. Duan, G. G. Bishop and J. G. Skofronick, 7th International Workshop on Interactions of Molecular Beams and Surfaces, Göteborg, Sweden, September, 1990.

30. Surface and Bulk Phonon Assisted Resonances with Surface Bound States in the Inelastic Scattering of He Atoms on $\mathrm{NaCl}$ (001), S. A. Safron, W. P. Brug, G. G. Bishop, G. Chern, E. M. Derrick, M. Deweese, J. Duan and J. G. Skofronick, American Vacuum Society, annual symposium, Toronto, Canada, October, 1990.

31. Surface Properties of CsF by He Atom Scattering, J. G. Skofronick, J. Duan, G. Chern, W. P. Brug, G. G. Bishop and S. A. Safron, 11th European Conf. on Surface Science, oct. 1-4, 1990, Salamanca, Spain.

32. Surface Dynainics of CsF by He Atom Scattering, J. Duan, W. P. Brug, G. Chern, G. G. Bishop, S. A. Safron and J. G. Skofronick, Southeastern Section of the American Physical Society, Atlanta, Georgia, November 15-17, 1990.

33. A High Resolution Helium Nozzle Beam from a Pulsed Source, E. S. Gillman, J. Duan, G. G. Bishop, W. P. Brug, S. A. Safron and J. G. Skofronick, Southeastern section of the American Physical Society, Atlanta, Georgia, November 15-17, 1990 .

34. Properties of Mgo as a Substrate for Laser Ablated High Temperature Superconductor Films, G. Chern, W. P. Brug, J. Duan, G. G. Bishop, S. A. Safron and J. G. Skofronick, Southeastern Section of the American Physical Society, Atlanta, Georgia, November 15-17, 1990.

35. Experimental Determination of Mgo (001) and Nio (001) Surface dispersion Curves via High-Resolution He Atom Spectroscopy, W. P. Brug, J. Duan, G. G. Bishop, G. Chern, S. A. Safron and J. G. Skofronick, Southeastern section of the American Physical Society, Atlanta, Georgia, November 15-1.7, 1990. 


\section{Papers Under preparation.}

1. Multiphonon Inelastic Scattering of Helium Atoms from Crystal Surfaces, G. G. Bishop, J. Duan, G. Chern, W. P. Brug, S. A. Safron, J. G. Skofronick and J. R. Manson. To be submitted to Physical Review Letters.

2. Surface Dynamics of Layered structures by Helium Atom Scattering, J. G. Skofronick and J.P. Toennies, A review article to be published in surface properties of Layered structures, Kluver Academic Publishers, The Netherlands.

\section{Proposals other than DOE.}

1. Study of the Surface Properties of High $\mathrm{T}_{\mathrm{C}}$ Materials, part of the Florida Initiative in Advanced Microelectronics and Materials proposal to DARPA by J. G. Skofronick, S. A. Safron and ot ier FSU MARTECH faculty, $\$ 55,000$ (for JGS and SAS), October, 1989-December, 1990, funded.

2. Structure and Dynamics of Chemisorption through He Atom Scattering on Crystalline Surfaces, National Science Foundation Visiting Professorship for Women, with M. E. Derrick, $\$ 136,000$, July, 1990-August, 1991, not funded, but will be resubmitted for the same period 1991-1992.

3. Dynamics of Crystal surfaces Both clean and with Adsorbates, supported by NATO and includes J. P. Toennies from the Max Planck Inst. in Göttingen and a collaborator from the Benedek/Miglio group at the University of Milan. Amount of Grant is $\$ 5,447.00$ to be used for travel support between the three institutions. 


\section{RLFERENCES}

1. G. Chern, J. G. Skofronick, W. P. Brug and S. A. Safron, Phys. Rev. B3E, 12828 (1989).

2. The design is that of P. S. Weiss, Ph. D. Thesis, University of California, Berkeley, 1986.

3. J. G. Sl:ofronick, W. P. Brug, G. Chern, J. Duan, S. A. Safron and G. Benedek, J. Vac. Sci. Technol. A8, 2632 (1990).

4. S. A. Safron, W. P. Brug, G. Cherr, J. Duan, J. G. Skofronick and J. R. Manson, J. Vac. Sci. Technol. A8, 2627 (1990).

5. S. A. Safron, W. P. Brug, G. G. Bishop, G. Chern, M. E. Derrick, J. Duan, M. E. Deweese and J. G. Skofronick, (Accepted by J. Vac. Sci. Technol. 1990).

6. G. Chern, W. P. Brug, S. A. Safron and J. G. Skofronick, J. Vac. Sci. Technol. A7, 2094 (1989).

7. G. Chern, J. G. Skofronick, W. P. Brug and S. A. Safron, Phys. Rev. B39, 12838 (1989).

8. S. A. Safron, W. P. Brug, G. G. Bishop, J. Duan, G. Chern, and J. G. Skofronick, (Accepted by J. Elect. Spectros. Related Phenom., Sept., 1990).

9. J. Duan, W. P. Brug, G. G. Bishop, G. Chern, S. A. Safron and J. G. Skofronick, Presented at the ECOSS-1.1 meeting, Salamanca, Spain (1990) and submitted to Surface Science.

10. W. P. Brug, preliminary work carried out in this laboratory.

11. G. Benedek, Surf. Sci. 61, 603 (1976).

12. G. Benedek and L. Miglio, in Ab Initio Calculations of Phonon Spectra, edited by J. Devreese, V. E. van Doren and P. E. van Camp (Plenum, New York, 1982).

13. T. S. Chen, F. W. de Wette and G. P. Alldredge, Phys. Rev. B15, 1167 (1977).

14. W. Kress, F. W. de Wette, A. D. Kulkarni and U. Schroeder, Phys. Rev. B35, 5783 (1987).

15. G. Brusdeylins, R. B. Doak and J. P. Toennies, Phys. Rev. B27, 3662 (1983).

16. G. Benedek, L. Miglio, G. Brusdeylins, J. G. Skofronick and J. P. Toennies, Phys. Rev. B35, 6593 (1987). 
17. L. I. Foldy and T. A. Witten, Solid state Commun. 37, 709 (1981); B. Segall and L. L. Foldy, Solid state Commun. 47, 593 $(1983)$.

18. F. W. de Wette, W. Kress and U. Schroeder, Phys. Rev. B33, 2835 $(1986)$.

19. S. A. Safron, G. Chern, W. P. Brug, J. G. Skofronick and G. Benedek, Phys. Rev. B41, 10146 (1990).

20. J. A. Stroscio, M. Persson, S. R. Bare and W. Ho, Phys. Rev. Lett. 54, 1428 (1985).

21. D. Evans, V. Celli, G. Benedek, J. P. Toennies and R. B. Doak, Phys. Rev. Lett. $\underline{50}, 1854$ (1983).

22. J. G. Skofronick, G. G. Bishop, W. P. Brug, G. Chern, J. Duan S. A. Safron and J. R. Manson, (Accepted by superlattices and Microstructures, June, 1990).

23. Multiphonon Inelastic scattering of Helium Atoms from Crystal Surfaces, G. G. Bishop, J. Duan, G. Chern, W. P. Brug, S. A. Safron, J. G. Skofronick and J. R. Manson (in preparation).

24. M. H. Yang and C. P. Flynn, Phys. Rev. Lett. 62, 2476 (1989). 


\section{FIGURE CAPTIONS}

1. Schematic of the He Atom-Surface (HAS) scattering apparatus showing the layout of the instrument. DP. TP, SP, $Y$ and $S$ refer to diffusion pump, turbomolecular pump, sublimation pump, valve and slit, respectively.

2. Schematic of the HAS instrument showing the geometry and the apparatus dimensions around the crystal target and the relationship of several. vector quantities associated with the incident and scattered beams. All dimensions are in $\mathrm{mm}$.

3. Surface phonon dispersion curves for $\mathrm{KBr}(001)$ over the ent ire surface Brillouin zone. The measured values are indicated by open circles, except for open triangies for those points with relatively weaker intensities. In (a) the data are plotted on top of slab calculations by Kress et al. (Reference 14) and in (b) they are plotted on the Green's furction calculation of Benedek and Miglio (Reference 12).

4. Surface phonon dispersion curves for $\mathrm{NaCl}(001)$ over the entire surface Brillouin zone. The measured values are indicated by closed circles, except for the closed triangles for those points with relatively weaker intensities. The data are plotted on top of the Green's function calcilation of Brnedek and Miglio (Keference 12). In () all the significant peaks in the time-of-flight spectra are included. In (b) the peaks in the time-of-flight spectra which correspond to phonon-assisted bound state resonances have been removed except for those lying very near to the predicted surface-localized modes.

5. Surface phonon dispersion curves for $\mathrm{RbI}(001)$ over the entire surface Brillouin zone. The measured velues are indicated by solid points. The data have been plotted on top of the slab dynamics calculation of de Wette et al. (Phys. Rev. B 35, 2476 (1987)). In the upper panel the calculation is for the unrelaxed surface while in the lower panel the calculation is for the relaxed surface.

6. A series of time-of-flight spectra converted to energy gain/loss plots for the specular scattering from $\mathrm{NaCl}$ (001) in the $<100>$ direction over the range of temperatures from $423 \mathrm{~K}$ to $673 \mathrm{~K}$. The intensity scale is arbitrary in each panel; the sharp peak is due to elastic collisions while the broad "foot" which grows with temperature is the inelastic multiphorion contribution. The smooth solid line is from theory (References 22 and 23) and depends mainly on the He-surface potential. The large oscillations at the left in the data are artifacts due to the Jacobian of the transformation from time-of-flight to energy.

7. A time-of-flight spectrum taken at the MPI, Göttingen, for the specular scattering of He from $A l$ (111) in the <112> direction, converted to an energy gain/loss plot. The solid line drawn 
through the multiphonon "foot" is from the model in References 22 and 23 and is fit only to the long-range tails which had been expanded by a factor of 10 . The rest of the distribution comes from the elastic scattering. Note that the "loss" jide is very different from those in Figure 6 because of the quite different form of the He atom-surface potentials in metals and in ionic insulators.

8. A plot of the specular He beam scattering intensity from $\mathrm{NaCl}$ (D01) in the <100> direction as a function of deposition time from a NaCl effusive source for two different substrate temperatures. The oscilations are due to layer-by-layer growth. The He incident wave vector in both is $7.5 \mathrm{k}^{-1}$.

9. Anyular distributions of the He scattering from NaCl under the conditions of the $198 \mathrm{~K}$ curve in Figure 8 , showing the Bragg scattering. (00) refers to the specular peak and the $(m, n)$ values refer to the Bragg peaks. The data in the upper panel were taken before the deposition began and in the lower panel after the deposition had caused the specular intensity to reach the bottom of the first oscillation. The deposition was halted while the angular distribution was measured. The change in intensities, which is repeatable, suggests changes in the corrugation of the He-surface potential.

1.0. Time-of-flight spectrum showing the specular scattering of He from LIF (001). $p_{0}$ and $d$ are the pressure in the nozzle and the diameter of the nozzle, respectively. The He heam has been produced by a pulsed valve operated at about 150K. Tise solid curve is a best-fit to the data with a full width at half of the maximum intensity (FWHM) of $16 \mu \mathrm{s}$, which is somewhat smaller than that found for the continuous source under similar conditions. 


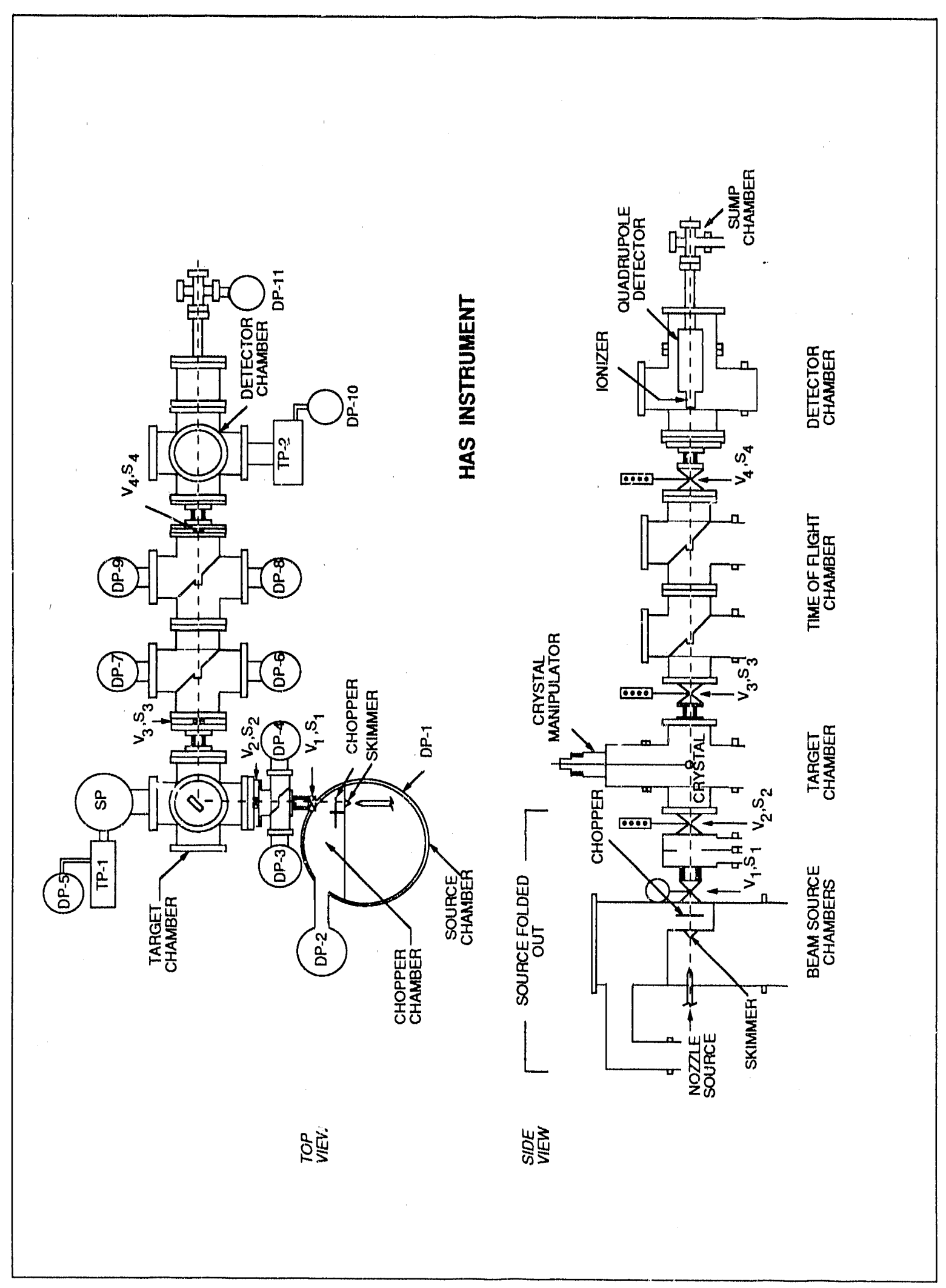

Figure 1 


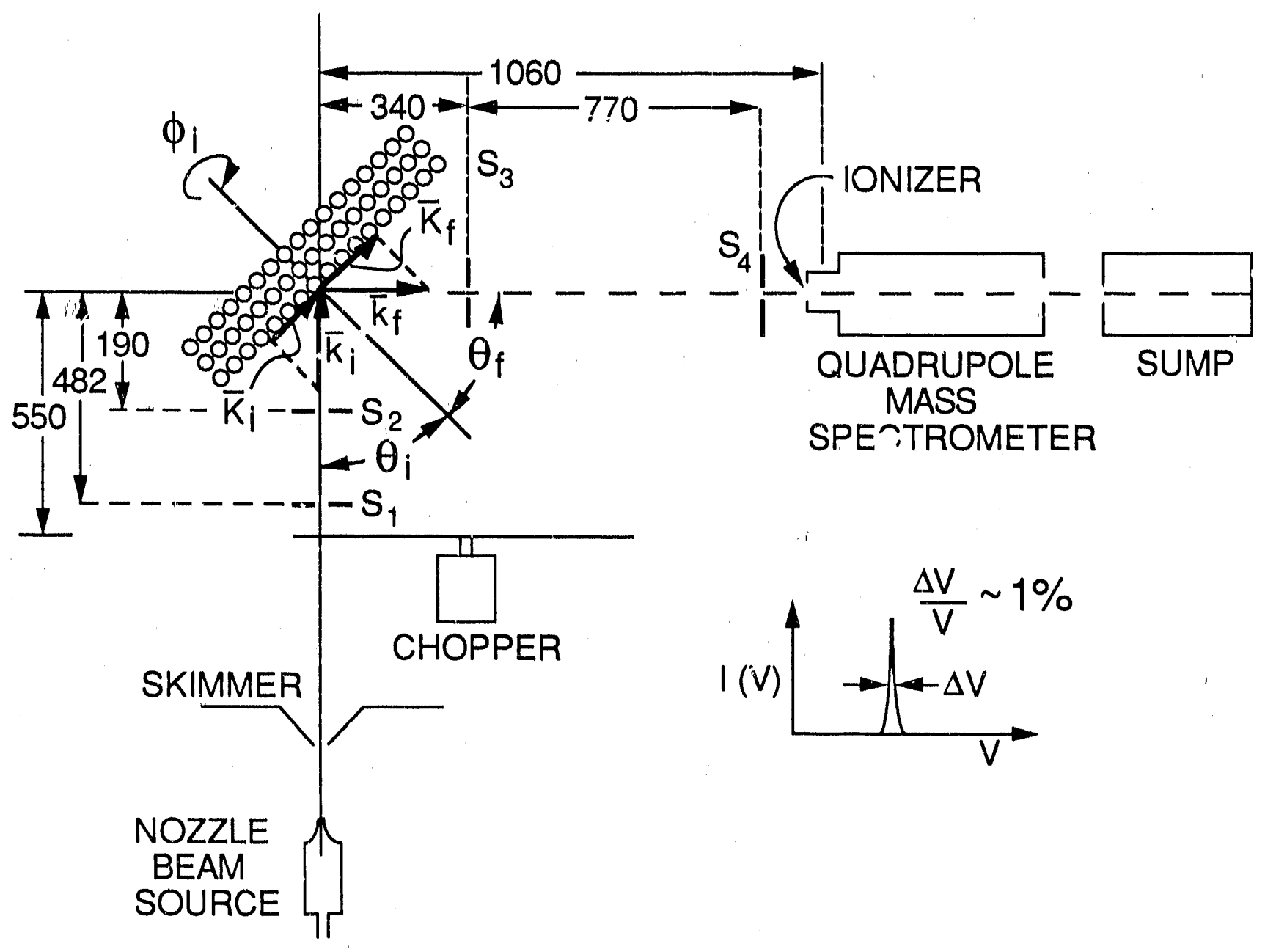

Figure 2 


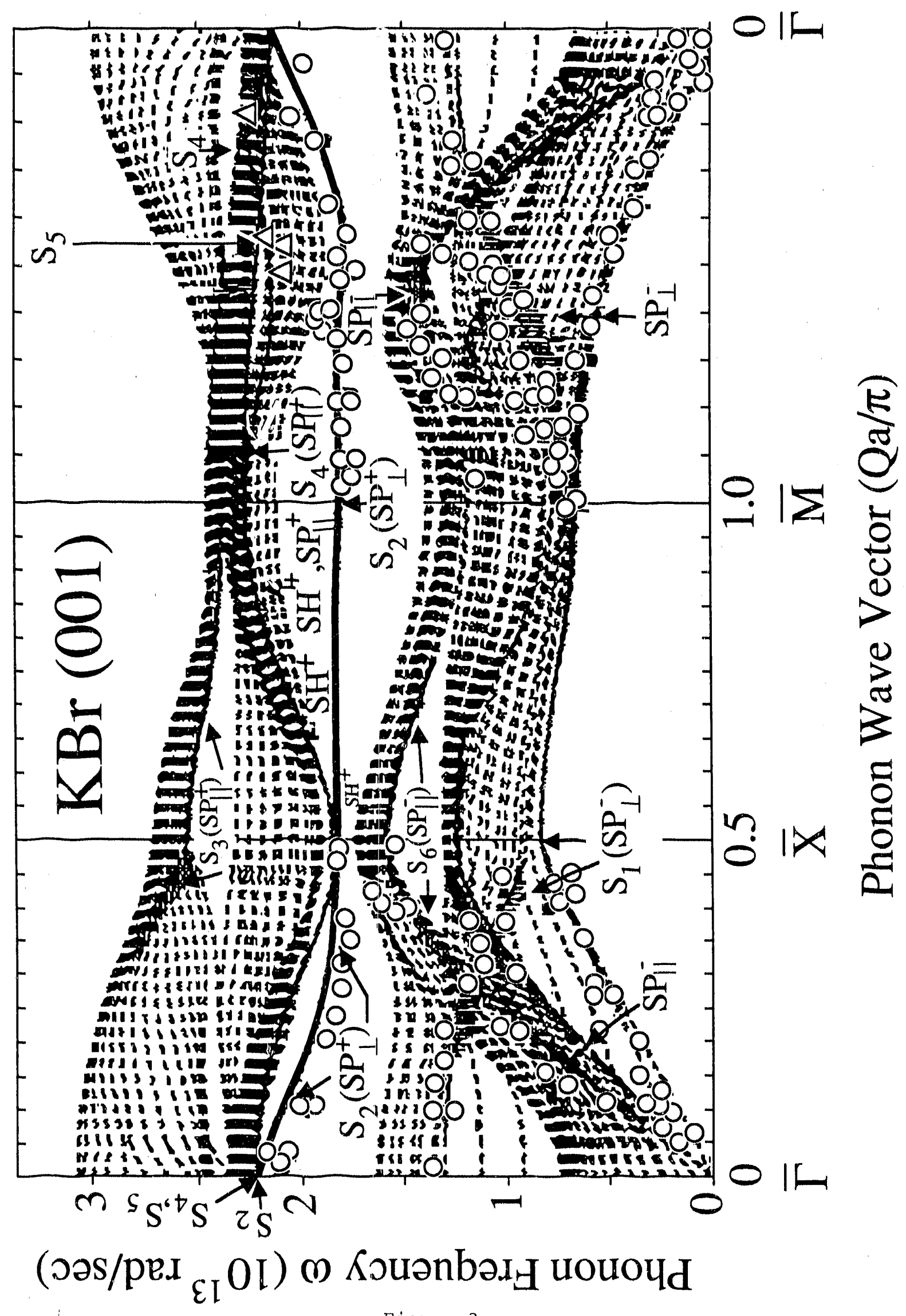

Figure $3 a$ 


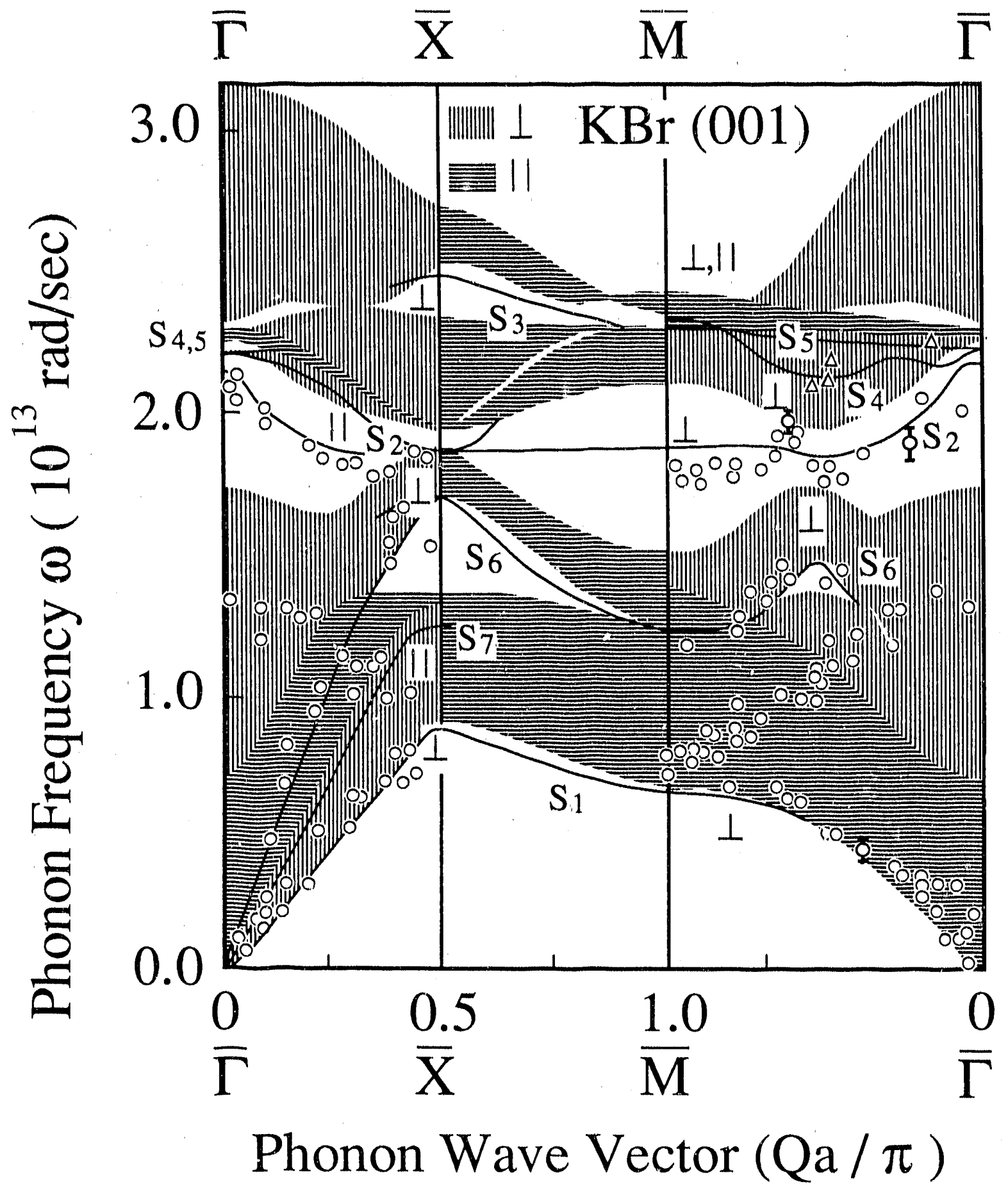

Figure $3 b$

SKOFRONICK (0)7 711.5 


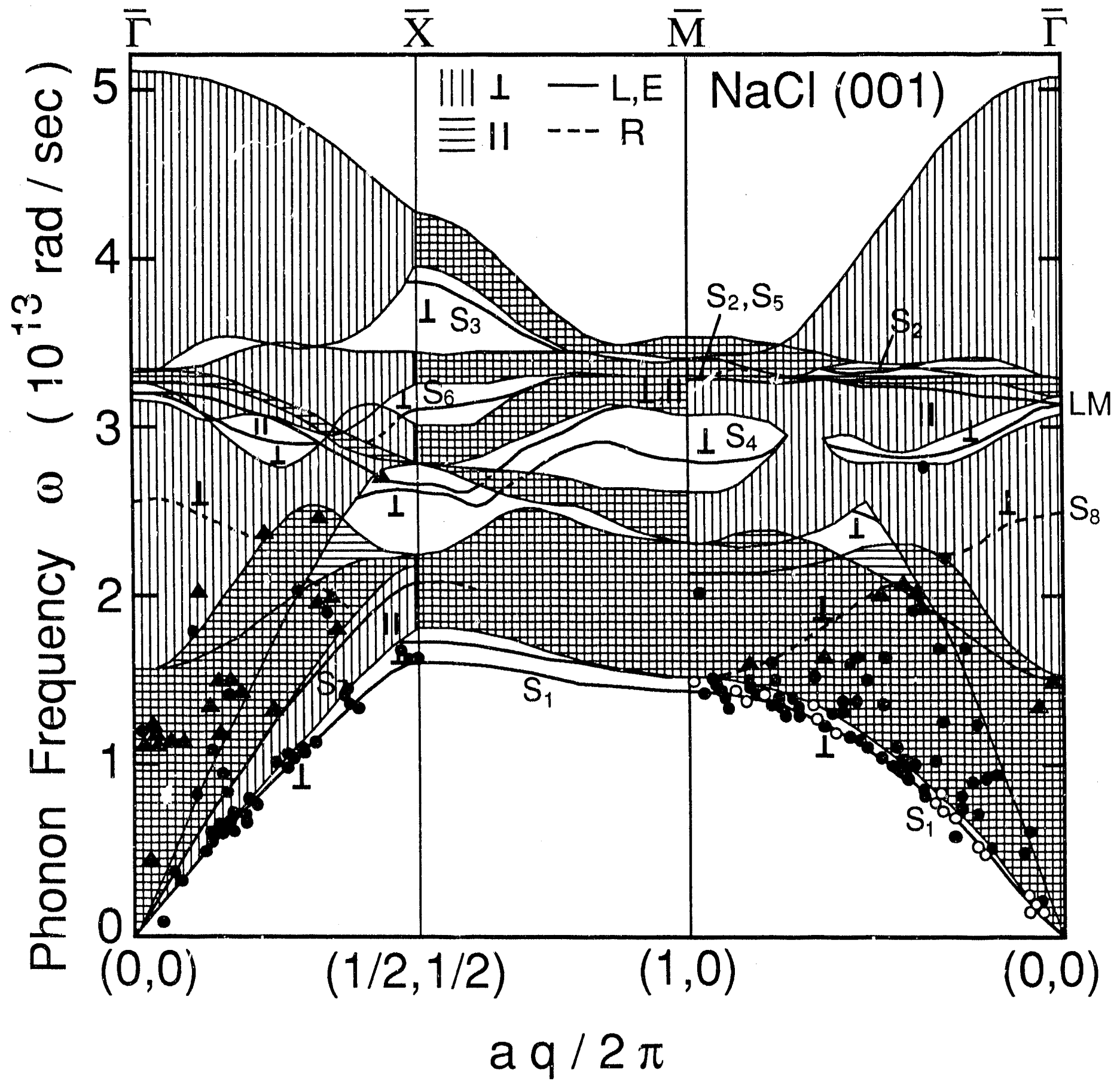




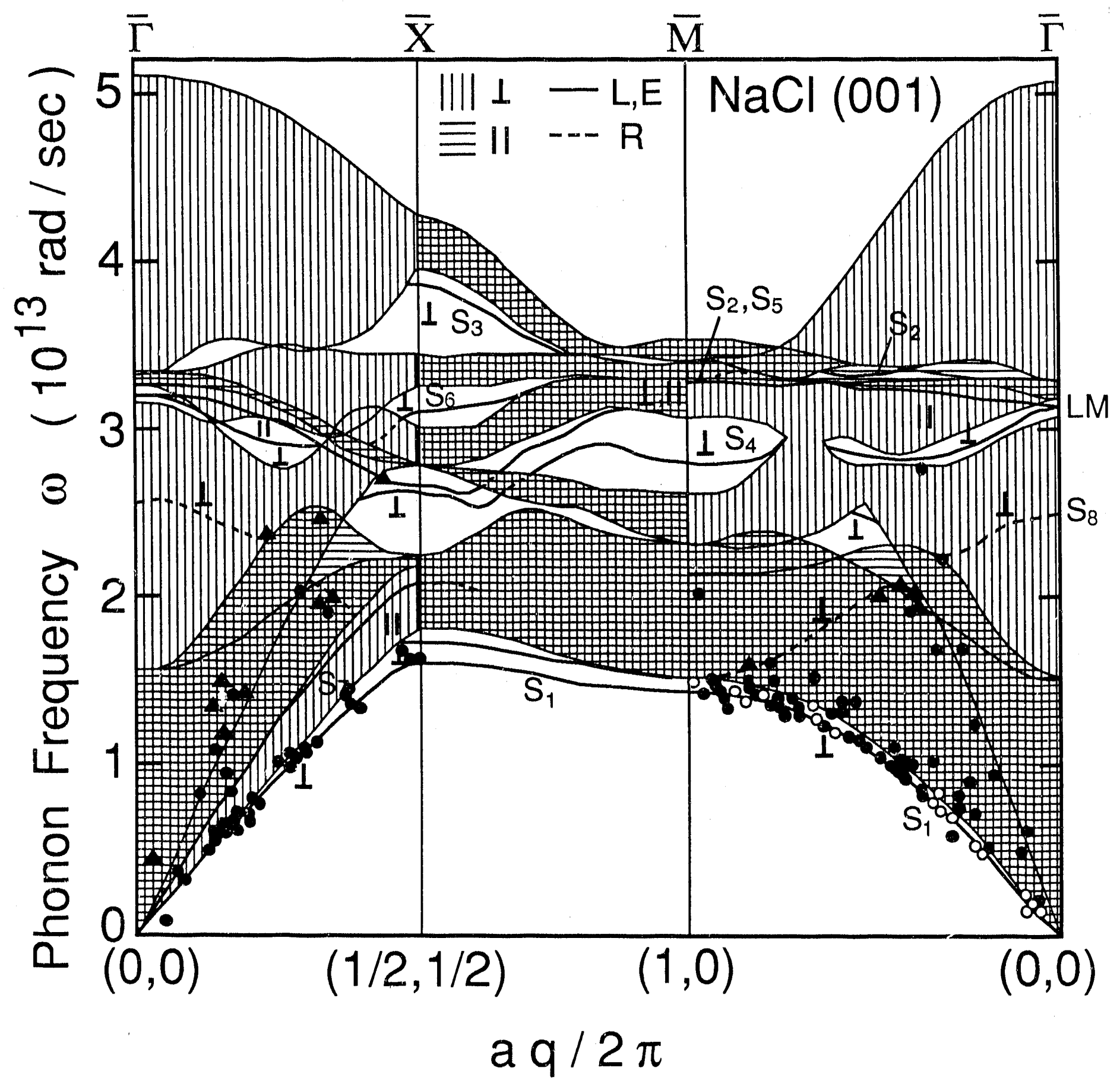

Figure $4 \mathrm{~b}$ 


\section{RbI unrelaxed}

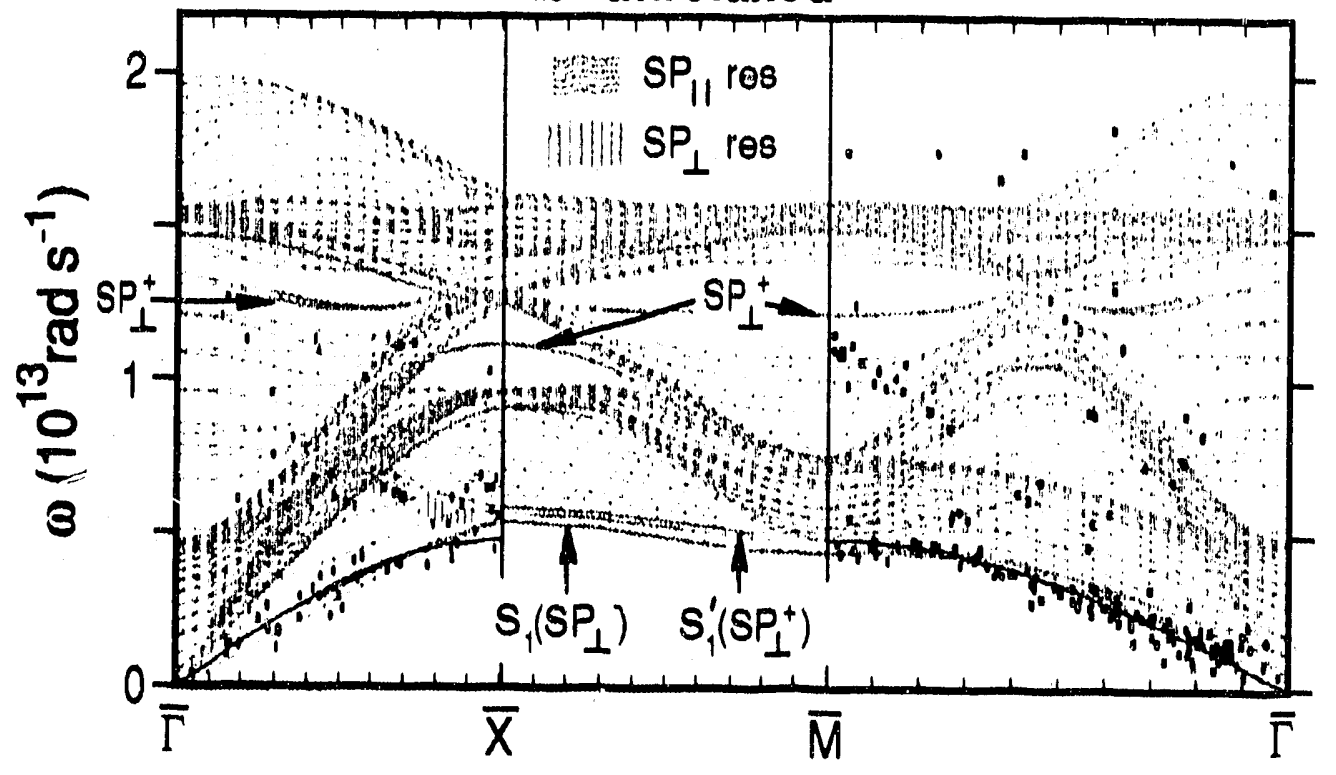

RbI relaxed

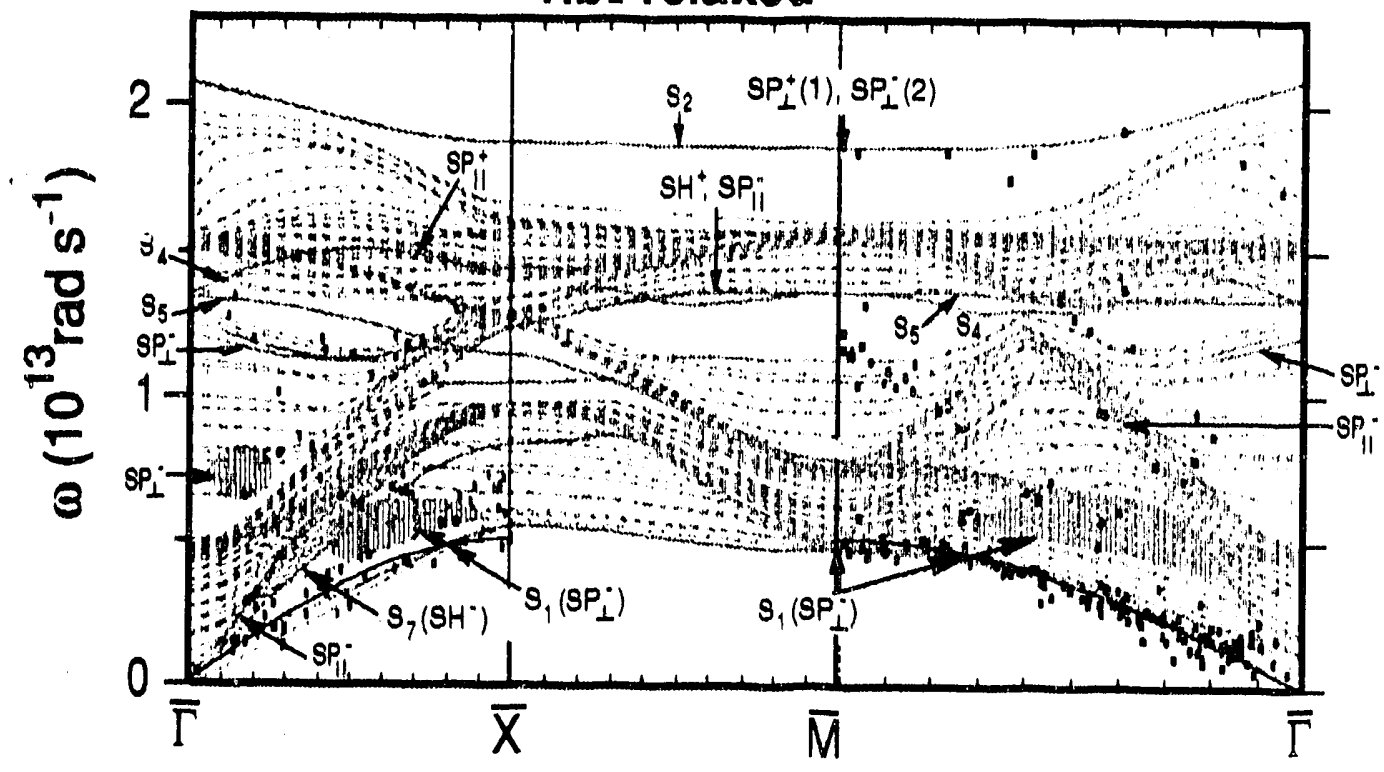



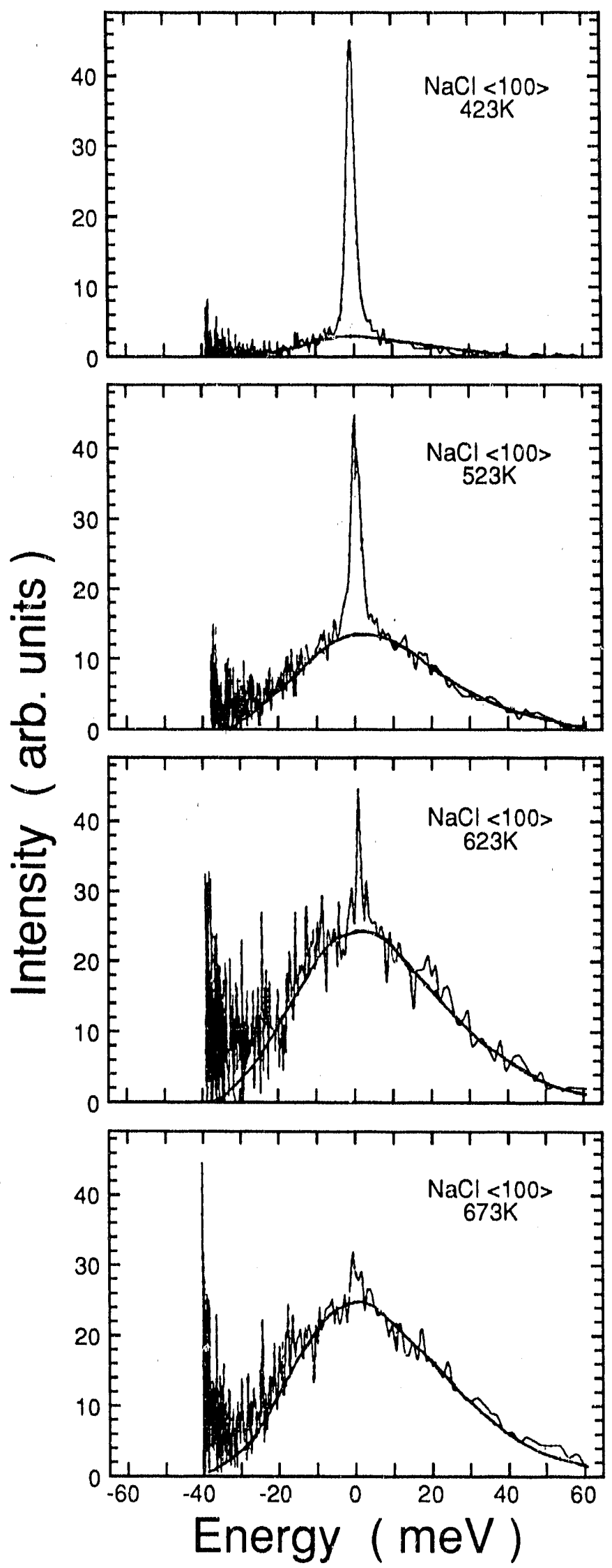

Figure 6 


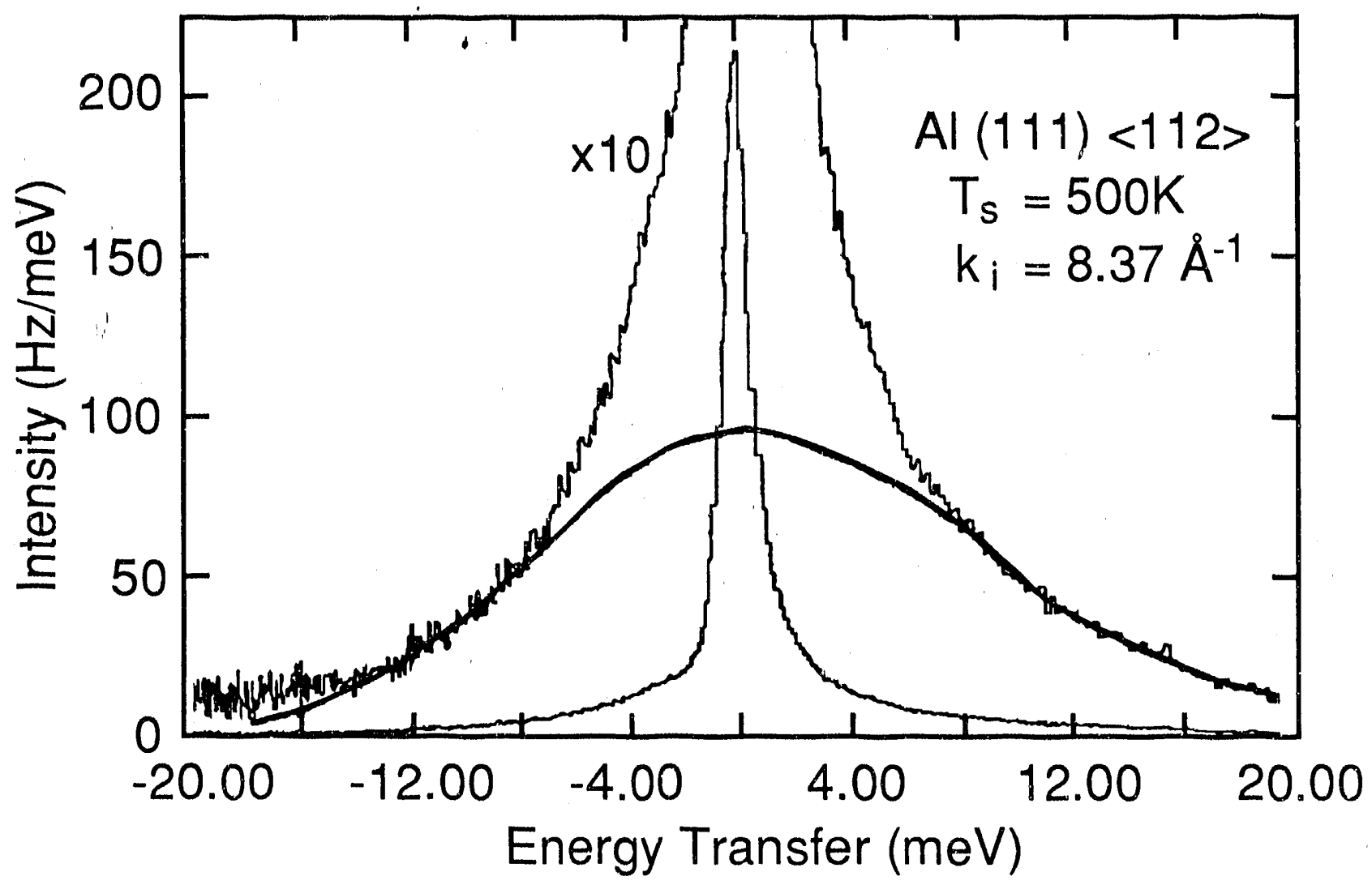

Eigure 7 


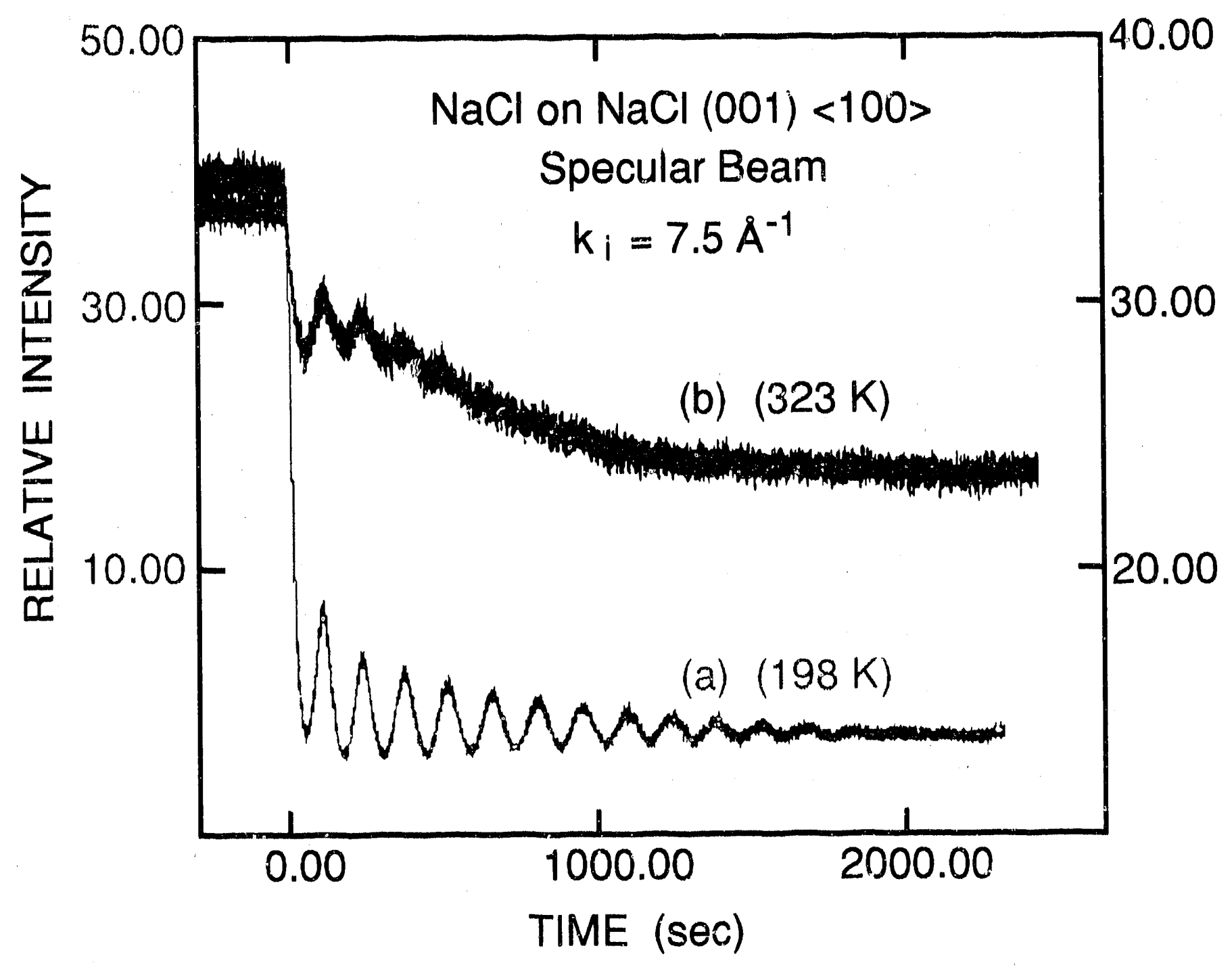

Figure 8 

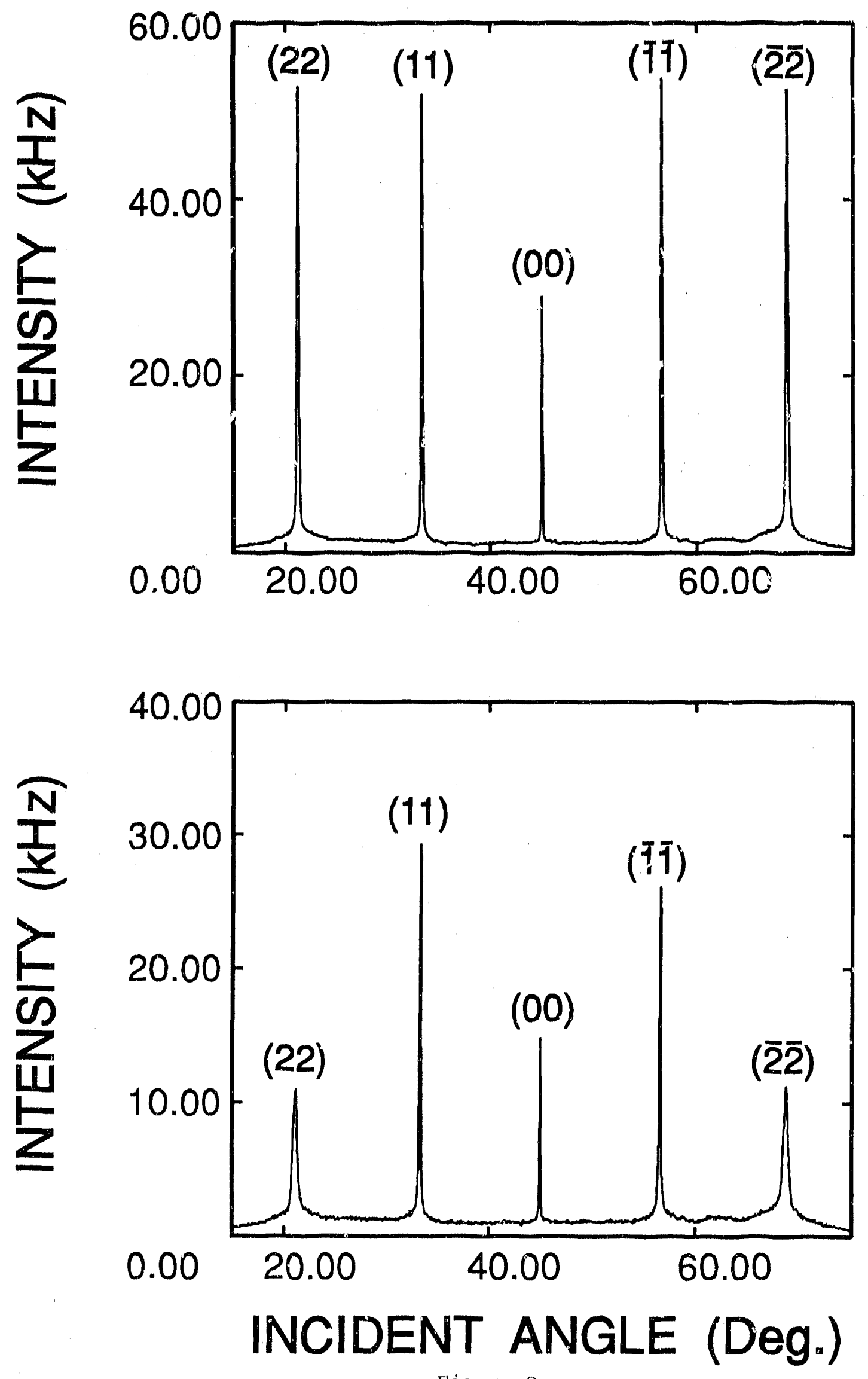

Figure 9 


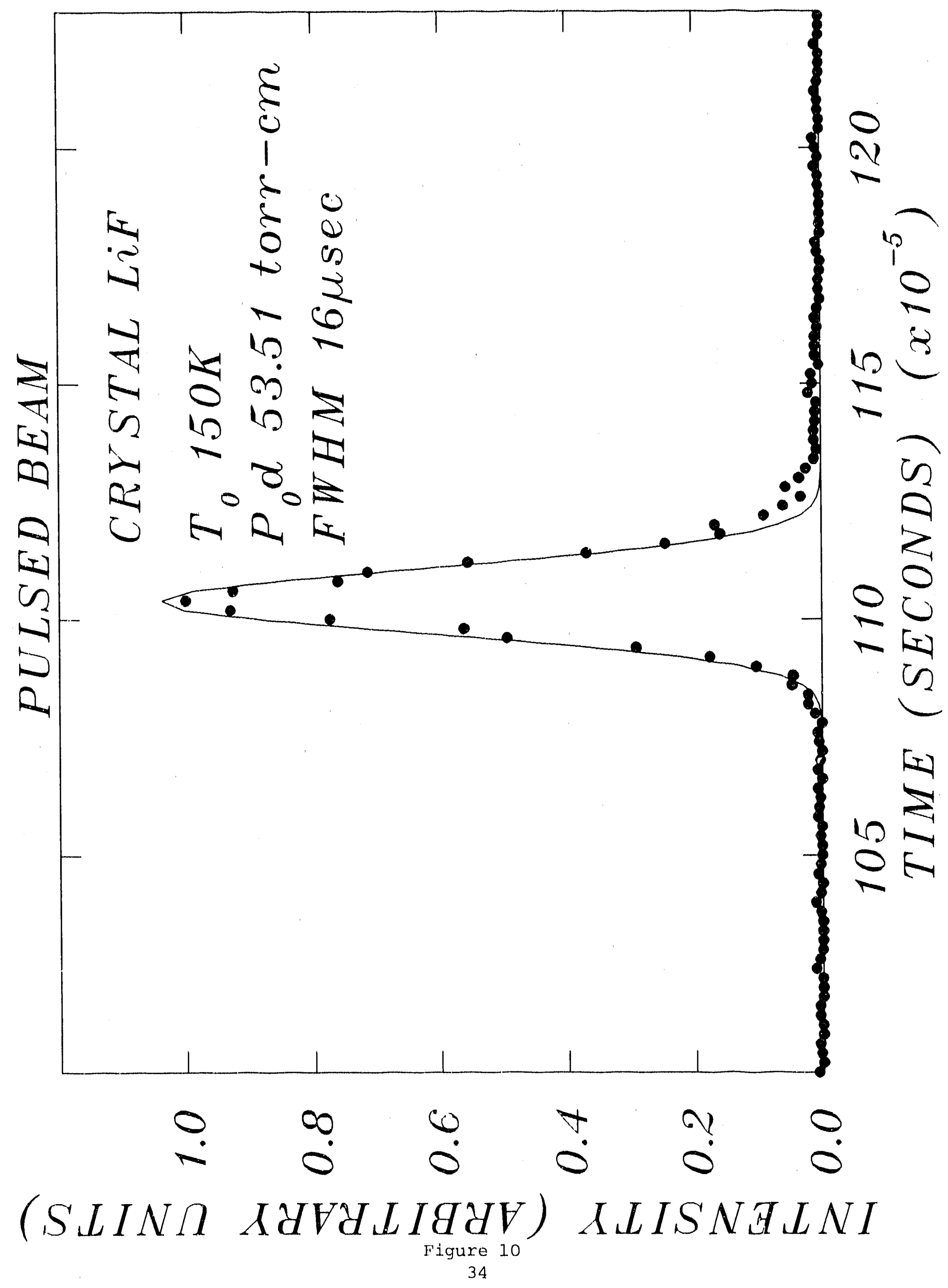



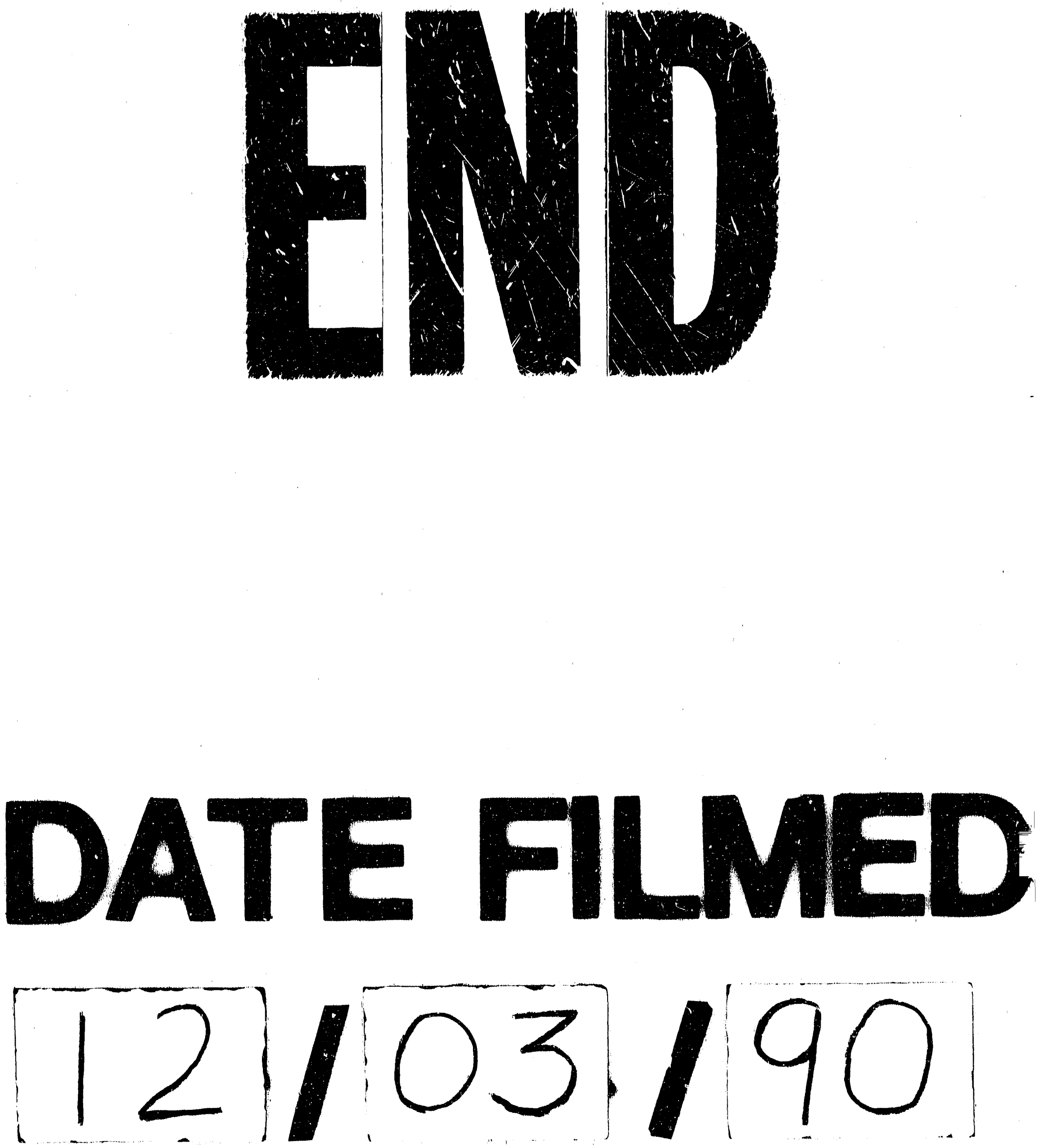
